\title{
Reconstructing the Source of Nominative- Absolutive Alignment in Two Amazonian Language Families
}

\author{
Spike Gildea and Flávia de Castro Alves
}

\begin{abstract}
In this article, we take the strong position that syntactic constructions can be reconstructed, first by identifying constructional cognates, then by identifying evidence for the directionality of constructional change that best explains the modern distribution of the cognate constructions from the hypothesized source construction. Further, we argue that the grammatical properties of the resultant constructions are often best explained by a combination of their etymological source(s) and the evolutionary pathways by which they arise. We illustrate these larger theoretical claims by reconstructing a typologically unusual set of constructions in the Jê and Cariban families, which present a rare ergative alignment pattern we call nominative-absolutive. Prior to 2010 this alignment pattern, which combines nominative free pronouns and absolutive verbal indexation, was held to be impossible, and it remains attested in very few language families. In the Jê and Cariban languages, this alignment type always occurs as part of ergative splits conditioned by TAM, which are again counter to previously claimed universals in that they are conditioned by future tense, imperfective aspects, and agent-oriented modalities. We reconstruct the sources of these nominative-absolutive constructions and then argue that the unusual formal properties and functional distributions of the nominative-absolutive clause types are both best understood as combinations of typologically unusual source constructions that follow well-established diachronic pathways of tense-aspect-mood renewal.
\end{abstract}

\section{Introduction}

As part of a volume on the topic of how syntax can be reconstructed successfully, this article offers multiple case studies that highlight the methodology by which cognate constructions can be identified in related languages. ${ }^{1}$ As a

1 For valuable comments and suggestions, we would like to thank audiences at the Symposium on Endangered Languages of Amazonia, University of Texas/Austin in 2007; the workshop

(C) SPIKE GILDEA AND FLÁVIA DE CASTRO ALVES, 2020 | DOI:10.1163/9789004392007_003

This is an open access chapter distributed under the terms of the CC BY-NC-ND 4.0 License. 
precondition to assessing the relative plausibility of competing reconstructions, we also examine arguments that make the case for specific, local directions of change. We assert that this sort of methodology could be used for any language family in which cognates are identifiable.

As part of the community that studies alignment typology, both synchronic and diachronic, we focus our reconstructions on an unusual subtype of ergative alignment that we (Gildea \& Castro Alves 2010) have named nominativeabsolutive, in which pronouns have a distinctive nominative form while verbal prefixes index the absolutive. This pattern of alignment was previously thought to be impossible (Dixon 1994: 95), which raises two interesting historical questions: First, how did this (apparently rare) pattern come to be, and second, does anything about its origins help us to understand why it appears to be so rare?

It is also notable that the Cariban and Jê constructions with nominativeabsolutive alignment constitute over half of the attested cases in which constructions with ergative alignment patterns occur on the wrong side of TAM-conditioned splits. Many have observed that in such alignment splits, the ergative is typically found in the past tense and perfective aspect, to which Dixon (1994: 101) adds non-agent-oriented modalities and positive polarity. However, these examples of nominative-absolutive alignment are conditioned also by nonpast tense, imperfective aspect, agent-oriented modalities, and negative polarity. By applying our methodology to exactly these typologically unusual constructions, we reconstruct not only the sources of the grammatical

Reconstructing Alignment Systems, University of Bergen in 20o9; two anonymous reviewers, and the other two editors of this volume. Spike Gildea would like to acknowledge support during collection of the Panare language data from NSF grant number BNS-8609304 (to Tom \& Doris Payne; thanks to speakers Prajedes Salas, Miguel Castillo, and Rafael Moncala), and during collection of the Katxuyana data from NSF grant number DBS-9210130 (thanks to speakers Honório Kaxuyana, Honorato Kaxuyana, João do Vale Kaxuyana, José Viana Kaxuyana, Manoel Kaxuyana, Eugênio Kaxuyana, Sebastião Kaxuyana, and Juventino Kaxuyana). Gildea is also grateful to acknowledge support from fellowships at the Research Centre for Linguistic Typology, LaTrobe University, Melbourne Australia (2006) and the Collegium de Lyon, in Lyon, France (2014-2015); some portions of this document were originally written at the RCLT and it took its final form at the Collegium de Lyon. Flávia de Castro is grateful to FAPESP and Universidade de Brasília for the grants that supported the projects Narrativas Timbira: documentação de corpora de fala, análise morfossintática sincrônica e evolução diacrônica do sistema de marcação de caso (2005-2006, FAPESP grant \#05/o03000-8) and Gramaticalização e reanálise nas línguas Jê Setentrionais: sobre a origem do alinhamento nominativo-absolutivo em Canela (2007-2009, Universidade de Brasília). She is very grateful to Canela speakers Anelivaldo Pihôc, Paulo Xu'crã, Ari Karompej, and Cornélio Piapite (in memoriam). Sem vocês, nada feito. 
patterns that are attested in the modern constructions, but also the conditions that allow them to arise on the "wrong" side of all the expected alignment splits. As such, this article also constitutes a contribution to the growing field of diachronic typology, specifically focused on the genesis of unusual alignment patterns in main clauses.

The main body of this article identifies the source of absolutive crossreferencing in both the Cariban and Jê language families as possessive prefixes on nominalized verbs; the sources of tense-aspect-mood morphology are specific nominalizers, together with, in some cases, adpositions or reduced forms of older main verbs that took these possessed nonfinite verbs as arguments in the source constructions. Crucially, in both families, nominalized transitive verbs already have the option of expressing their notional A arguments in an oblique phrase. This source is attested as creating main clause ergativeabsolutive case-marking in the past tense in Timbira (Castro Alves 2010) and in multiple tenses and aspects in Cariban (Gildea 1998, 2012). However, in the modern nominative-absolutive constructions, the uniquely case-marked A of the source nominalization is lost. In a subset of the source constructions that we reconstruct, it was suppressed in the source due to coreference conditions; we reconstruct the remainder of the source constructions with the ergative-marked A, but then we suggest that it is lost uniquely in the nonpast tenses, replaced by former topic pronouns that were reanalyzed as nominative pronouns.

The article is organized as follows. Section 2 introduces the Cariban and Jê language families, as well as the unusual nominative-absolutive alignment pattern. Section 3 briefly introduces our theoretical framework, Diachronic Construction Grammar (DCxG), and situates our methodology within that framework. Sections 4-6 contain the details of the reconstructions: Section 4 characterizes the reconstructed nominalizations and their argument structure, Section 5 reconstructs source complex clauses in which the ergative A is suppressed due to coreference to the S/A of the matrix verb, and Section 6 reconstructs source complex clauses in which the ergative A was retained, but then replaced by topic pronouns and (unmarked) NPs in focus position. In the conclusions in Section 7 , we suggest that the reconstructions help us to make sense of the typologically anomalous patterns identified in Section 2.

\section{Nominative-Absolutive Alignment as a Puzzle for Reconstruction}

To set the stage for the larger arguments, we first briefly introduce the Jê and Cariban language families (2.1), then some crucial properties of the nominativeabsolutive alignment pattern found in these languages (2.2). 


\subsection{The Jê and Cariban Language Families}

The Jê language family consists of nine languages, many with named dialects in the literature, all spoken in Brazil (cf. Gildea \& Castro Alves 2010: 174); these are in turn often linked to a larger set of languages (whose membership remains disputed) called the Macro-Jê stock (Rodrigues 20o9; see classification of Jê in Castro Alves 2010: 439-40 and of Macro-Jê in Ribeiro \& van der Voort 2010: 547 ). In this article, we focus on four of the six Northern Jê languages: Apinajé, Timbira (Canela Apãniekrá, Canela Ramkokamekrá, Krahô, Parkatêjê, Pykobjê, Krĩkatí), Mẽbêngôkre (Kayapó, Xikrín), and Kĩsêdjê (Suyá). We leave aside the fifth Northern Jê language, Panará, as it does not present the nominative-absolutive pattern and the sixth, Tapayúna, whose published work (Camargo 2015) we became aware of after this article was written. Our examples for these languages come from Castro Alves' field notes, and also from a number of published sources: for Apinajé, Oliveira (2003, 2005); for the Canela Apãniekrá dialect of Timbira, ${ }^{2}$ Castro Alves (2004, 2008, 2010); for Mẽbêngôkre, Stout \& Thomson (1974), Reis Santos (2001), Castro Alves \& Reis Silva (2007), Salanova (2007, 2008); and for Kĩsêdjê, Santos $(1997,1999)$ and Nonato (2014). For additional data on these languages, cf. references in Castro Alves (2010) and Gildea \& Castro Alves (2010: 175).

The Cariban language family consists of some 25 extant languages spoken in northern South America, primarily north of the Amazon in Brazil, Venezuela, and the three Guianas, with outliers spoken in Colombia and south of the Amazon in Brazil. In this article, we focus on two languages that belong to different genetic subgroupings (Gildea 2012: 442-446): Panare (Panare-Pemón Macro Group; Venezuelan Branch), spoken in Central Venezuela and Katxuyana (Parukotoan Group), spoken north of the Amazon in the Brazilian state of Pará and northern Brazil. Gildea has field notes for both languages, but the data we rely on here can all be found in prior publications: for Panare, Gildea (1998), Mattéi Muller (1994, 2007) and Payne \& Payne (1999, 2013); for Katxuyana, Gildea \& Castro Alves (2010).

For the purposes of the argument in this article, the details of the classifications are not important except in that they limit the depth of the reconstructions to the most restricted genetic unit that contains all of the languages in focus. All four of the Jê languages in focus belong to a sub-unit within Jê, which limits the scope of our reconstructions to the proto-language of that

2 Since all the Timbira data in this article come from a single dialect, Canela Apãniekrá, for the rest of the article we avoid the collective term, Timbira, in favor of the individual term, Canela. The reader should keep in mind that other Timbira dialects may present important differences to the patterns described here. 
sub-unit, Proto-Northern Jê. In contrast, there is no reliable classification of the Cariban family that combines the Parukotoan Group and the Panare-Pemón Macro-Group in any smaller unit than the entire family; this allows us to utilize prior reconstructions of Proto-Cariban morphology and syntax (especially Gildea 1998, 2012) as a resource for identifying the source constructions in question in this article. We turn now to a characterization of the alignment pattern to be reconstructed.

\subsection{Alignment Typology and Nominative-Absolutive Alignment}

Alignment typology is the study of how languages code the basic clause-level semantic information of who did what to whom, observing how the single core argument of an intransitive clause (the $S$ ) aligns with one or both of the core arguments of a transitive clause $(\mathrm{A} \& \mathrm{O})$. $^{3}$

Basic morphosyntactic properties that languages generally use to distinguish core arguments are (nominal) case-marking, (verbal or auxiliary) indexation of person/number, and order of core argument constituents vis-à-vis the verb. Additional syntactic patterns are commonly added to this basic list, including constituency of core arguments vis-à-vis the verb, coreference with reflexive (4th person) morphology, coreference restrictions between core arguments of one clause and core arguments of another (either conjoined or subordinated to the clause in question), and analogical (often considered derivational) relationships between clause types (e.g. active versus passive, or main versus relative clauses). Having identified these grammatical properties for the $S$ of an intransitive clause and the $\mathrm{A}$ and $\mathrm{O}$ of a transitive clause, we can then seek out the ways in which the properties of S align with those of A and/or O.

The label nominative-accusative, commonly called just accusative, describes the situation where $\mathrm{S}$ and A pattern together (the nominative) in opposition to the $\mathrm{O}$ alone (the accusative). In contrast, the label ergative-absolutive, commonly called just ergative, describes the situation where $\mathrm{S}$ and $\mathrm{O}$ pattern together (the absolutive) in opposition to the A alone (the ergative). There are a number of languages in which one or more of the core arguments for a lexically specified subset of verbs do not present the same grammatical patterns. In particular, a subset of A or $\mathrm{O}$ might be marked differently from the normal, or canonical patterns (e.g., dative-subject or locative-object), a pattern sometimes

3 We use Dixon's $(1979,1994)$ terms, S, A, and O, but without endorsing Dixon's assertions regarding their theoretical status as "semantico-syntactic primes" (cf. Queixalós \& Gildea 2010, Haspelmath 2011 for discussion of problems with these labels). For us, they are merely a convenient way to exposit patterns that link transitive subject $(\mathrm{A})$ and/or transitive object $(\mathrm{O})$, with intransitive subject (S). 
labeled noncanonical marking (Aikhenvald et al. 2001) or semantic alignment (Donohue \& Wichmann 2008). This is also quite frequently found with the single core argument of intransitive verbs, where a subset of $S$ might be marked like $\mathrm{A}$ and another subset like $\mathrm{O}$, a situation labeled variously Active-Stative, Active-Inactive, Agent-Patient, Split S, split intransitive or, again, semantic alignment. These types are almost universally recognized in typological surveys and textbooks (e.g. Dixon 1979, 1994; Comrie 1989; Payne 1997; Givón 20o1; Croft 2003; Dryer 2007; etc.).

Each of these labels describes a pattern that can be observed and described in any given construction in any given language. It is at the level of pattern that each of these alignments is a descriptive label: for example, it is relatively common for a nominal or pronominal case-marking pattern in a given construction, say, a past-tense clause type to be ergative-absolutive while verbal indexation is nominative-accusative. However, the label to be applied to the entire construction is not neutral: based on the case-marker, such a construction is labeled ergative, with no sub-label to recognize the accusative verbal indexation. The opposite combination, in which an accusative case-marking pattern co-occurs with an ergative or absolutive verbal indexation pattern, was not attested at the time this convention was established, cf. this quote from Dixon (1994: 95):

Cross-referencing systems are thus basically pronominal (with the affixes having developed from free-form pronouns, in some earlier stage of the language). We would expect them to be on a nominative-accusative pattern, since this characterizes pronouns at the extreme left of the hierarchy ... What we can predict is that, if there is a 'split' of this kind, then bound prefixes will be accusative and case-marking on free forms will be ergative. This is exactly what is found.

However, we have identified multiple languages in which there are constructions characterized by Nominative-Accusative patterns everywhere except in verbal indexation, which is absolutive: this is the pattern we call nominativeabsolutive (Gildea \& Castro Alves 2010). As an initial illustration of the nominative-absolutive type, consider these clauses from Panare $(1 \mathrm{a}-\mathrm{b})$ and Canela (2a-b). 
(1) Panare nominative-absolutive (examples from Mattéi Muller 1994) ${ }^{4}$ $\mathrm{s}-\mathrm{V} \quad \mathrm{s}$ Aux $\quad \mathrm{S}$
a. $y$-u-të-sejpa
$k \ddot{e j}$
kën
${ }_{3} S_{-}$S $_{\text {A }}$-gO-FUTURE 3 S.ANIM.COP 3.ANIM.DIST
's/he will go'
$\mathrm{o}-\mathrm{V}$
A.Aux
A
b. y-ama-sejpa
këj
kën
3O-throw.away-FUture 3A.ANim.cop 3.ANIM.Dist
's/he will throw away it/him/her.'

(2) Canela nominative-absolutive (Castro-Alves 2004) ${ }^{5}$

\begin{tabular}{llll}
$\mathrm{S}$ & $\mathrm{TAM}$ & $\mathrm{s}-\mathrm{V}$ & AUX \\
a. $w a$ & ha & i-wrik & nare \\
\multicolumn{1}{c}{ IRLS } & IS-descend.NF & NEG \\
\multicolumn{3}{c}{ 'I will not descend' }
\end{tabular}

\begin{tabular}{clll} 
A & TAM & o-V & AUX \\
b. $w a$ & ha & i?-pir & nare \\
1 & IRLS & 3-grab.NF & NEG \\
\multicolumn{4}{c}{ I will not grab it (e.g., the knife).' }
\end{tabular}

In both (1a) and (2a), S occurs as a free pronoun (postverbal in Panare, clause initial in Canela) and in Panare S controls auxiliary agreement; in both clauses, $S$ is also indexed on the verb as a person-marking prefix. In both $(\mathrm{lb})$ and $(2 \mathrm{~b})$, A occurs as a free pronoun in the same clause location and case-form as the $\mathrm{S}$ pronoun, and in Panare, A controls auxiliary agreement; in both clauses, $\mathrm{O}$ is indexed on the verb as a person-marking prefix. In this initial illustration, A and $\mathrm{O}$ show clearly distinct patterns in the case form of pronouns (Canela), order and constituency (both Panare and Canela), auxiliary indexation (Panare), and/or verbal indexation (both Panare and Canela). S aligns with A in terms of pronominal case form (Canela), order (Panare and Canela), and auxiliary agreement (Panare), whereas $\mathrm{S}$ aligns with $\mathrm{O}$ only in the verbal indexation forms. As such, $\mathrm{S}$ and A share a nominative pattern of pronominal case,

4 Orthographic symbols in Panare follow their IPA values with the following exceptions: $\ddot{e}[ə]$, $j[\mathrm{~h}], y[\mathrm{j}], \operatorname{ch}[\mathrm{t}]$, ' $[?]$, and vowel length indicated by doubling the vowel rather than a colon diacritic: $a a$ [a:].

5 Orthographic symbols for Jê languages cited in this article take their IPA values. 
constituent order, and auxiliary agreement, while $\mathrm{S}$ and $\mathrm{O}$ share an absolutive pattern of verbal indexation. These patterns are explored in some detail in Gildea \& Castro Alves (2010) for the Jê languages Canela, Kĩsêdjê, and Apinajé, and for Cariban languages Panare and Katxuyana.

We turn now to the problem of labeling the alignment type of such constructions: for the previously attested mixtures, i.e., ergative case-marking alongside nominative agreement, the presence of ergative case-marking is sufficient for labeling a construction "ergative". In order to apply this precedent, we must determine whether the most important criterion for choosing the label is that the case-marking is ergative, or whether any ergative pattern anywhere in the construction would be sufficient. If the construction is to bear the label of the case-marking pattern, then the nominative versus accusative pronouns would force us to label these constructions "nominative-accusative". However, given the tradition of labeling certain constructions in Mayan languages as ergative even though case-marking is neutral, we conclude that the existence of any marked ergative morphological pattern justifies the use of the term "ergative", and as such, the existence of absolutive verbal indexation would require us to consider these constructions as representing a subtype of ergative (cf. Gildea \& Castro Alves 2010: 161). Yet there is something odd about either solution in that (i) both patterns are present, and (ii) the patterns that are morphologically marked are exactly those that we expect to be unmarked: the nominative (unique pronominal case forms and auxiliary agreement) and the absolutive (verbal indexation prefixes). To prevent carelessly lumping these constructions in with either the accusative or the ergative type, and to index the categories that receive explicit morphological realization, we have adopted the hybrid label nominative-absolutive.

If we assume, as we did in Gildea \& Castro Alves (2010: 192ff), that the presence of absolutive indexation makes these constructions a subtype within the ergative category, then we encounter a second typologically rare pattern in the tense-aspect-mood-polarity values that condition this subtype of ergative construction. In each language where it is attested, the nominative-absolutive alignment pattern is conditioned by specific values of tense, aspect, mood, and polarity, whereas other alignment patterns are conditioned by the remaining tense-aspect-mood-polarity values. This phenomenon is known as TENSEASPECT-BASED SPLIT ERGATIVITY, which itself possesses a characteristic pattern, as observed by Dixon (1994: 101):

An ergative system is less likely to be employed when the clause refers to something that has not yet happened (in future tense), or is not complete 
(imperfective aspect) or did not happen (negative polarity), or where the emphasis is on the agent's role (imperative or hortative moods). ${ }^{6}$

However, Gildea \& Castro Alves (2010:191) show that the nominative-absolutive constructions in Cariban and Jê are mostly conditioned by exactly the wrong tenses, aspects, moods, and polarity, as indicated in Table 2.1.

The only tense value that conditions the nominative-absolutive alignment in our data is future, two of the four aspects are progressive and imperfective (the completive value is consistent with Dixon's expectation and the Panare "nonspecific" aspect is arguably neutral, cf. Payne \& Payne 2013: 212-213), the desiderative mood certainly puts emphasis on the agent's role (whereas the "evaluative" moods emphasize the speaker's evaluation rather than the agent's role), and all negative clauses in the three Jê languages must occur in the nominative-absolutive alignment. It is remarkable that the nominativeabsolutive construction is on the wrong side of every single one of the semantic values expected to condition ergative alignment.

These facts require some explanation. The nominative-absolutive pattern itself is sufficiently rare that its existence violates a proposed universal; one wonders why the pattern should be so rare, or, as its corollary, why it should exist at all. Similarly, one might ask why, in terms of typological correlations, the nominative-absolutive clause type in Cariban and Jê better matches the predicted distribution of a non-ergative alignment type. We believe that richer understanding may be gained from considering how an alignment type comes

TABLE 2.1 Tense-aspect-mood distinctions that condition nominative-absolutive

\begin{tabular}{|c|c|c|c|c|c|}
\hline & Canela & Apinajé & Kĩsêdjê & Panare & Katxuyana \\
\hline Tense & & & FUTURE & FUTURE & \\
\hline \multirow[t]{3}{*}{ Aspect } & PROGRESSIVE & PROGRESSIVE & PROGRESSIVE & NONSPECIFIC & IMPERFECTIVE \\
\hline & CONTINUOUS & CONTINUOUS & CONTINUOUS & & \\
\hline & COMPLETIVE & & COMPLETIVE & & \\
\hline Mood & EVALUATIVE & & & DESIDERATIVE & \\
\hline Polarity & NEGATIVE & NEGATIVE & NEGATIVE & & \\
\hline
\end{tabular}

6 Dixon (personal communication) indicates that the one case of a polarity-based splitergative has been disconfirmed in subsequent research, and as such, he would no longer include negative polarity in this passage. 
into being. One would expect that very rare patterns arise from conditions that are equally rare, whether from unusual properties of expected source constructions, or from complex scenarios of change (cf. Givón 1979, 2009; Malchukov 2010; and for the same observation in the domain of phonology, Blevins 2004). Counter-examples to typologically general patterns also offer us the possibility of new perspectives on the forces that create the more typical patterns. We return to the question of explanation in Section 7 , after having reconstructed the genesis of this alignment pattern in the two families where it is most widely attested, Cariban and Jê. The next section introduces a preliminary sketch of our methodology for reconstructing morphosyntactic patterns, which depends crucially on the notion of construction.

\section{3}

\section{Diachronic Construction Grammar}

We begin with the assertion that the relevant comparanda for reconstructing morphosyntax are not so abstract as schematic patterns, but are rather the much more concrete combination of morphemes and patterns that are packaged together in individual constructions. The framework of Construction Grammar ( $\mathrm{CxG})$ offers multiple ways to formalize the notion of construction (cf. Goldberg 2006, Ch. 10), but for our purposes, neither the details of the formalism nor the theoretical postulates associated with the framework are central. ${ }^{7}$

For these reconstructions, it is sufficient that constructions have both formal and semantic properties, and that these are arbitrarily linked to one another in a way analogous to the link between lexical form and meaning. Crucial to our work is that the formal and semantic properties of an innovative construction are not readily reducible to a combination of the formal and semantic properties of their component parts. Once we recognize the construction as the relevant synchronic unit, we can identify the formal and semantic properties of individual constructions in individual languages in search of similarities that are too consistent to be explained as products of chance. That is, we can identify cognate constructions.

As explained in the introduction to this volume, the identification of syntactic cognates is controversial, both in theory and in practice. Rather than enter into the theoretical debate, we choose to explain our method carefully, then show that it works. In brief, our theoretical definition is: Morphosyntactic

7 See Traugott \& Trousdale (2013) and Barðdal \& Gildea (2015) for detailed discussions of the diachronic implications of the formal architecture of $\mathrm{CxG}$ models. 
cognates are constructions that are so similar in form and meaning that they logically must come from a common origin (the etymological meaning of the term cognate). Operationally, we seek to identify constructional cognates via their formal correspondences: we seek cognate grammatical morphemes, including personal pronouns, verbal indexation prefixes, case-markers, and tense-aspect-mood-polarity markers, both those found bound to verbs and those that are free words, such as the auxiliaries in Cariban and Jê. We also identify less concrete grammatical patterns (such as constituency or coreference restrictions) that are found in the syntactic constructions where these morphological cognates occur, identifying in particular those patterns that are identical or extremely similar across the distinct constructions in which the cognate morphology appears.

In addition, the semantics of candidate constructions must be either identical or relatable by known pathways of semantic change. Comparing candidate constructions, when we detect parallel morphology and syntax plus semantic identity or plausible semantic connection, we then consider the possible explanations for how they might have come to exhibit such similar form and meaning. The logical possibilities are coincidence, contact, or shared origin. When we can rule out coincidence or contact as plausible explanations, we conclude that the shared form and meaning must come from a common origin, and hence that the constructions are cognate.

In Section 4, we seek out the constructional cognates in both language families that contain the grammatical morphology and syntactic patterns that coalesce into the attested nominative and absolutive properties found in the various nominative-absolutive constructions.

The next step is then to explain the modern distributions of the relevant cognate constructions: did one modern construction give to rise to the others, or did all of them arise from some older construction that is no longer attested? This is the question of directionality, not in the absolutist sense of the unidirectionality debates in grammaticalization literature, but rather in the concrete details of each individual construction. ${ }^{8}$ Here, we rely on three metrics.

8 As pointed out by a reviewer, the idea of "local directionality" (Willis 2011: 414-416) seems to be an intellectual antecedent to the kind of more concrete directionality that concerns us here. Our ideas reflect Willis' in that we are less concerned with possible vs. impossible changes and more with relative plausibility of specific hypothesized changes. Our ideas differ in how we argue for the relative plausibility of competing hypotheses about direction of change - in particular, we do not consider logical arguments about which source could have more readily created alternative constructions that might facilitate reanalysis during first language acquisition. 
- First, which of these constructions is more widely attested in each family? To the extent that some constructions are widely attested in the family, we are forced to reconstruct them farther back than we are forced to reconstruct the others. This does not necessarily mean that they are older than constructions with more limited distribution, just that they are too widespread to be a relatively recent innovation, whereas constructions with more limited modern reflexes might be old, but they might also be quite recent.

- Second, in which constructions do the cognate morphemes in question occur with consistent meanings? To the extent that morphemes occur with consistent meanings in multiple, heterogeneous constructions, but have distinct meanings when they occur together in a single construction, this single construction is most likely to be an innovative reanalysis (cf. Gildea 1998: 39-41).

- Third, when the set of cognate constructions can be aligned with sets of constructions that have gone through an attested historical change in unrelated languages (e.g. locative constructions > progressive, cf. Heine 1994, Bybee et al. 1994, etc.), then we can appeal to the record of attested change to motivate positing a parallel change in the languages in question. Especially important to this final metric is that some changes appear to be unattested (e.g. a progressive suffix becoming a sequence of a nominalizing suffix followed by a locative postposition), and as such, no reconstruction should posit such a change without exceptionally good arguments of the first two types.

We turn now to the details of the reconstructions. Nominalizations

Subordinate clause structures for Proto-Cariban and for northern Jê have been reconstructed in Gildea (1998) and Castro Alves (2004, 2010), respectively. These reconstructions are not controversial, as basically the same subordinate clause structures can be found synchronically in nearly all the modern languages of both families, making it fairly automatic to reconstruct them to the two proto-languages. In the remainder of this section, we briefly summarize the evidence in favor of reconstructing subordinate clause grammar to Proto-Cariban (Section 4.1) and Proto-Northern-Jê (Section 4.2). 


\subsection{The Proto-Cariban Possessed Nominalization Construction}

Based on cognates found in 24 of the 25 extant languages, Gildea (1998: 119128) reconstructs five distinct nominalizing suffixes, of which two play a role in this article: *-ri 'ACTION NOMINALIZER' and *-ne 'A NOMINALIZER'. Based on cognates found in Panare, Kapóng and †Tamanaku, Gildea (2003: 17) reconstructs the suffix *-ceti 'NOMINALIZER' to the Proto-Venezuelan Branch of Cariban (for full classification, cf. Gildea 2012: 445). In addition, Gildea demonstrates that verbs bearing these nominalizations are all inalienably possessed by their notional absolutive ( $\mathrm{S}$ of intransitive and $\mathrm{O}$ of transitive), expressed as a preceding free NP possessor in a tight possessor-possessed constituent or as a bound possessive prefix/proclitic on the nominalized verb. The notional A of the transitive nominalized verb need not occur (indeed, it cannot occur when the verb bears *-ne 'A NZR'), but if it does, it can only be in an oblique phrase, marked in most Cariban languages by a modern reflex of the dative postposition *wija 'AGT'.

Consider the illustrative examples of intransitive nominalized verbs in (3). In (3a), the intransitive verb ehito 'begin' bears the nominalizing suffix - $r \dot{t}$ 'NZR' and is possessed by the preceding NP konoho 'rain', its notional S; this entire $\mathrm{NP}$ is then the object of the postposition me 'ESSIVE'. In ( $3 \mathrm{~b})$, the intransitive verb $w u$-të 'INTR-GO' bears the cognate nominalizing suffix - $n$ 'NZR' and is possessed by the preceding noun waiki 'deer', its notional S; this NP is then the object of the postposition mënkai 'like'. In both cases, the possessor and the possessed form a clear constituent, a tight NP.

(3) Nominalized intransitive clauses in Katxuyana (a) and Panare (b)

\begin{tabular}{|c|c|c|c|c|}
\hline$[[\mathrm{PSSR}$ & V-NZR ] & $\mathrm{P}]_{\mathrm{PP}}$ & & \\
\hline - [konoho & ehitor ] & $m e]$ & wahtawi, & tiihüra. \\
\hline konoho & e-hito-rï & me & wahtawï & t-iri-hüra \\
\hline rain & DETR-begin-NZR & ESS & when.being & 3-make-NEG \\
\hline
\end{tabular}

(DV.Imoho yiitohu-oo3)

(lit. 'when being like the beginning of the rain, it is not done')

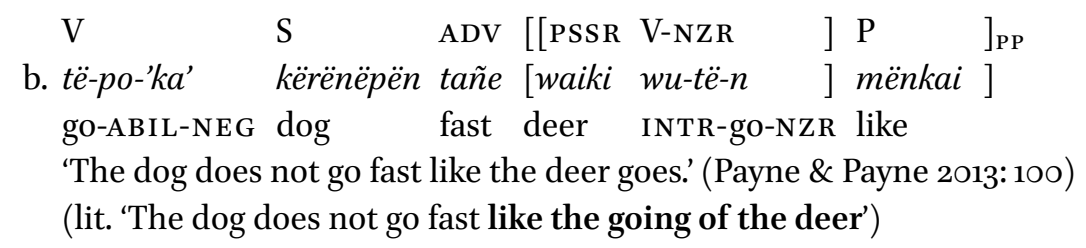


The prefix wu- 'INTR' in Panare is a reflex of a prefix found across the Cariban family on the $\mathrm{S}_{\mathrm{A}}$ subclass of nominalized intransitive verbs (Meira 2000: 205206); ${ }^{9}$ in Katxuyana this prefix has been lost with nominalizations that are possessed by the third person (cf. its absence in ehitor 'beginning' in $3 a$ ).

Now consider the representative examples of transitive nominalized verbs in (4), where the possessor is the notional O and the notional A (when it occurs) bears the dative postposition. In (4a), the transitive verb $y$-ii-tohu 'the making (of it)' bears the circumstantial nominalizing suffix -tohu and is possessed by the preceding noun, imoho 'field', which is the notional O; the notional A is the PP katxuyana wïy 'by the Katxuyana'. This entire NP is then the subject of the predicate PP soro wara 'like this'. In (4b), the transitive verb $y$-uku- $n$ 'the eating of it' bears the nominalizing suffix $-n$ and is possessed by the preceding noun paaru 'banana'; the notional A is expressed as the animate in visible third person pronoun kën, which occurs at the end of the sentence bearing the dative postposition úya.

(4) Nominalized transitive clauses in Katxuyana (a) and Panare (b)

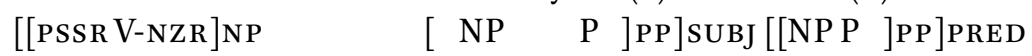

a. Imoho yiitohu, imoho y-iri-tohu Katxuyana wïya, soro wara. field REL-make-CIRC.NZR Katxuyana AGT soro wara 'The making of (their) fields, by the Katxuyana, is like this.'

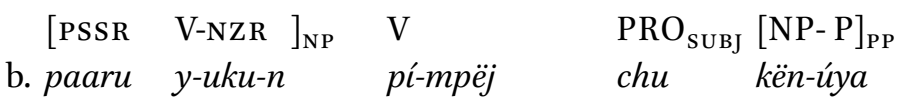
banana TRN-eat-NZR want-IMPRF.T 1SG 3.ANIM.INVIS-DAT 'I want him to eat bananas.' (Payne \& Payne 2013: 393) (lit. 'I want the eating of bananas by him.')

In the absence of the absolutive NP, the absolutive prefixes are identical to the prefix paradigms found on possessed nouns and postpositions, as seen in Table 2.2. Different allomorphs are conditioned by the initial segment of the possessed noun, consonant-initial ( -C) and vowel-initial ( -V). In Panare, forms possessed by the first person or by a preceding NP show leftward stress

9 Payne \& Payne (2013: 234, 237) consider the underlying form of the prefix $w u$ - to be $u$-, which they sometimes write with an asterix ${ }^{*} u$, as though it were a reconstructed form. They posit that it becomes $w$ - when word-initial (i.e., when not preceded by a personal prefix). Given the widespread occurrence of $w$ - across the family, we endorse Meira's (2000) reconstruction of ${ }^{*} w$ - rather than ${ }^{*} u$ - 


\begin{tabular}{|c|c|c|c|c|}
\hline & \multicolumn{2}{|c|}{ Katxuyana } & \multicolumn{2}{|l|}{ Panare } \\
\hline & $-\mathrm{C}$ & $-\mathrm{V}$ & $-\mathrm{C}$ & $-\mathrm{V}$ \\
\hline ISG & $\varnothing-$ & $y-$ & $\varnothing^{\wedge}$ & $y^{\wedge}$ \\
\hline $2 S G$ & $o-$ & oy- & $a-, o-$ & $a y-, o-$ \\
\hline $3^{S G}$ & $i-$ & $\varnothing$ & $i, y \ddot{i}-$ & $y, t y-$ \\
\hline $1+2$ & $k \ddot{-}$ & $k$ & - & - \\
\hline preceding $\mathrm{NP}$ & NP Ø- & $\mathrm{NP} y$ - & $\mathrm{NP} \varnothing^{\wedge}$ & $\mathrm{NP} y^{\wedge}$ \\
\hline
\end{tabular}

shift (indicated by $\wedge$ ), thereby disambiguating first and third person when both show the same $y$ - prefix (cf. Payne \& Payne 2013: 75; Gildea 2012: 453-454). Note that many nominalized intransitive verbs take the prefix $w$ - 'INTR' (Panare) / ' $\mathrm{S}_{\mathrm{A}}$ ' (Katxuyana), and as such take the allomorphs for consonant-initial stems; the exception is the second person prefix $o$ - '2', which is a coalescence of the prefix $a$ - with a following $u$ or $w$.

Constructions with cognate morphology and identical argument structure patterns are found across nearly all modern Cariban languages (Gildea 1998: 104-127), making it vanishingly unlikely that the similarity is due to coincidence. Given the geographic dispersal of these languages, as well as the many differences in phonology and vocabulary, contact is an equally unlikely explanation. These very concrete constructions could only be so parallel because they come from a common origin. Accordingly, Gildea (1998) reconstructs this type of subordinate clause to Proto-Cariban. Before demonstrating the relevance of this reconstruction to the origins of the Cariban nominativeabsolutive clause types, we turn to the parallel reconstruction of nonfinite clauses in Northern Jê.

\subsection{The Proto-Northern-Jê Possessed Nonfinite Verb Construction}

The key morphological element of the Jê reconstruction is the formal distinction between two forms of the verb, a shorter form that is generally considered the finite verb versus a longer form that is generally considered the nonfinite verb. This distinction is marked idiosyncratically in each verb, such that sometimes the verb pairs differ in initial consonant or vowel, sometimes by a final consonant or vowel, sometimes via entirely suppletive forms, and for a few verbs, there is no phonological distinction. To illustrate, we present the finite and nonfinite forms for a selection of verbs in Canela (Table 2.3), Kĩsêdjê (Table 2.4), Apinajé (Table 2.5), and Mẽbêngôkre (Table 2.6). 
TABLE 2.3 FINITE versus NONFINITE verb forms in Canela (Castro Alves 2010: 448-449)

\begin{tabular}{|c|c|c|c|c|c|}
\hline FINITE & NONFINITE & 'gloss' & FINITE & NONFINITE & 'gloss' \\
\hline$t \int a$ & tfãm & 'get up' & $t f a$ & tfãm & 'build' \\
\hline ape & зpen & 'work' & kura & kuran & 'kill' \\
\hline wro & wrak & 'descend' & to & ton & 'make' \\
\hline aktfa & piktfar & 'laugh' & apro & apror & 'take' \\
\hline amti & pimtir & ‘dream’ & $\eta \tilde{\mathcal{J}}$ & $\tilde{\partial} r$ & 'give' \\
\hline amrã & ykwar & 'cry' & teet & $t \int e t$ & 'roast' \\
\hline$\eta \tilde{\partial} r$ & $\tilde{s} t$ & 'sleep' & $a k^{h} \varepsilon p$ & $a k^{h} \varepsilon p$ & 'cut' \\
\hline
\end{tabular}

TABLE 2.4 FINITE versus NONFINITE verb forms in Kĩsêdjê

\begin{tabular}{|c|c|c|c|c|c|}
\hline FINITE & NONFINITE & 'gloss' & FINITE & NONFINITE & 'gloss' \\
\hline$t \tilde{\varepsilon}$ & $t \tilde{\varepsilon} m$ & 'leave' & ku & kuru & 'eat' \\
\hline ggre & ygrere & 'dance' & $p \tilde{\iota}$ & pĩrĩ & 'kill' \\
\hline rwa & rwak & 'descend' & $k \tilde{~}$ & kõm & 'drink' \\
\hline$n \tilde{\jmath}$ & $n \tilde{o} r \tilde{\jmath}$ & 'lay' & $\eta \tilde{J}$ & $\eta \tilde{t} t \tilde{}$ & 'give' \\
\hline
\end{tabular}

TABLE 2.5 FINITE versus NONFINITE verb forms in Apinajé

\begin{tabular}{llllll}
\hline FINITE & NONFINITE & 'gloss' & FINITE & NONFINITE & 'gloss' \\
\hline$t \tilde{e}$ & tem & 'go' & $k u$ & $k u r$ & 'eat' \\
$t f a$ & $t f a m$ & 'stand' & pide & piden & 'capture, arrest' \\
amiti & pimtir & 'dream' & pubu & pubun & 'see, look at' \\
jako & jakor & 'smoke' & kura & kuran & 'hit; batter; break'
\end{tabular}

TABLE 2.6 FINITE versus NONFINITE verb forms in Mẽbêngôkre

\begin{tabular}{|c|c|c|c|c|c|}
\hline FINITE & NONFINITE & 'gloss' & FINITE & NONFINITE & 'gloss' \\
\hline$t \tilde{e}$ & tẽm & 'go' & kurwa & kurwaj & 'hit' \\
\hline re & rere & 'swim' & pumũ & pumũn & 'see, look at' \\
\hline$\eta r \varepsilon$ & grere & ‘sing’ & arẽ & arẽn & 'tell' \\
\hline mua & mrrr & 'cry' & $k r \tilde{e}$ & krẽn & 'eat' \\
\hline
\end{tabular}


At this point, two things should be clear. First, the distinction between finite and nonfinite verbs is robust and pervasive in these four Northern Jê languages: nearly all transitive and intransitive verbs have two distinct forms, readily distinguishable from one another. Second, there is no easily reconstructable morphological form that marks this difference - both forms of each individual verb will need to be reconstructed one by one to the common ancestor of these four languages, proto-Northern-Jê. ${ }^{10}$

For our purposes in this article, the data from these four languages is sufficient to establish that the morphological categories of FINITE VERB and NONFINITE VERB are both reconstructable as morphological categories, even in the absence of a reconstruction of each verb form.

Having established the reconstructibility of the morphological category of nonfinite verbs in Northern Jê, we turn to the question of the syntactic environments in which we can encounter the category in each modern language. The term 'NONFINITE' has been chosen because in all four languages, this form occurs as a base for the further derivation of deverbal nouns and it also occurs as the nucleus of subordinate clauses, in particular those that function as an NP in a matrix clause. ${ }^{11}$

Castro Alves (2010: 458-463) presents synchronic examples from Canela, Apinajé and Mẽbêngôkre, and given that all three present virtually the same argument structure, she reconstructs that argument structure to Proto-Northern-Jê. In an almost exact structural parallel to the Proto-Cariban nominalized verb, the Proto-Northern-Jê nonfinite verb is inalienably possessed by its notional absolutive, which may be either a free NP that forms a tight constituent with the possessed nonfinite verb, or simply a bound pronoun, represented as either a pronominal clitic or a prefix. In contrast, the notional A, if it occurs at all, must be marked by a modern reflex of the postposition $t \varepsilon$ 'GENITIVE'.

We illustrate this structure with examples from Apinajé and Kĩsêdjê. In (5a), the intransitive nonfinite verb tẽm 'go.NF' is possessed by its notional $\mathrm{S}$, the first person proclitic ic- ' 1 '. In ( $5 \mathrm{~b})$, the cognate nonfinite verb thẽm 'go.NF' is possessed by the preceding free noun i-nã 'my mother'; the two form a constituent, as indicated by the brackets.

10 In fact, the Finite-NONFinite distinction is also attested in Southern Jê languages Shokleng (Urban 1985), and Kaingang (Wiesemann 1972, 2002), so it will surely reconstruct all the way back to Proto-Jê. Ribeiro \& van der Voort (2010: 553) reconstruct a Proto-Amazonian-Jê "abstract nominalizer" * $r$, which may be implicated in the history of the nonfinite form, and they also identify a possible cognate $-r$ - 'nominalizer' in the Macro-Jê language Karajá.

11 Santos (1999) goes so far as to argue that in Kĩsêdjê, the "long form" of a verb is not just a nonfinite verb, but could actually be analyzed as a lexical noun. 
(5) Nominalized intransitive clauses in Apinajé (a) and Kĩsêdjê (b)

$(\mathrm{s}-\mathrm{V})$

[PSSR-PSSD]

a. in-mã $\left.\quad\left[\begin{array}{llll}{[a k u n i ̃} & k o t & \text { ic-tem }\end{array}\right] \quad j a\right] \quad p u-b a$

ApInajé

1-DAT woods DIR 1-go.NF DEF RP-fear

'I'm afraid of walking in the woods.' (lit. 'my walking') (Oliveira 2005: 236)

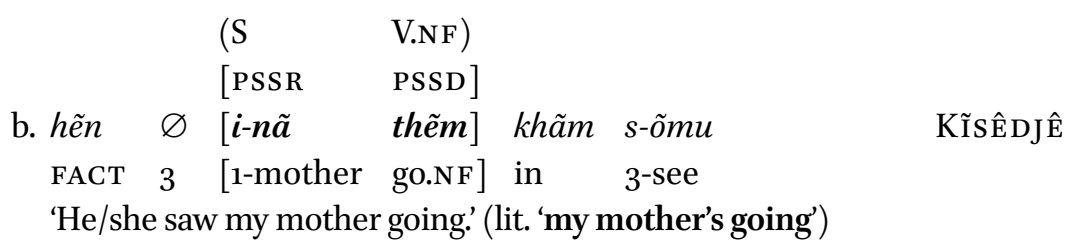

(Nonato 2014: 134)

In (6a), the transitive nonfinite verb nõr 'lie on' is preceded by its possessor, the notional $\mathrm{O}$ [pikap ja] 'the earth'. In (6b), the nonfinite verb khuru 'eat.NF' is possessed by the third-person prefix $\varnothing$ - ' 3 ', which refers to the notional $O$, the thing that is eaten. In both $(6 \mathrm{a}-\mathrm{b})$, the notional $\mathrm{A}$ of the nonfinite transitive verb is an oblique argument, labeled 'ERGATIVE' by the authors in question: ate '2.ERG' in (6a) and $i-n \tilde{a}=r e$ 'my mother=ERG' in (6b). Castro Alves (2010) reconstructs this ergative postposition to a marker of genitive.

(6) Nominalized transitive clauses in Apinajé (a) and Kĩsêdjê (b)

$$
\begin{array}{lll}
\text { (A } & \text { O } & \text { V.NF) } \\
\text { PP } & \text { [Possr } & \text { Possd] }
\end{array}
$$

a. $p a \quad$ na paØ-inmãate pikapja nõr

Apinajé

1.EMPH RLS 1 1.DAT 2.ERG earth DEF lie.on.NF

prõm ket

want NEG

'It is I who don't want you to lie on the ground.' (Oliveira 2005: 86)

(lit. 'the lying on of the earth by you')
(A
o-V.nf)
$[\mathrm{PP}$
PSSR-PSSD]

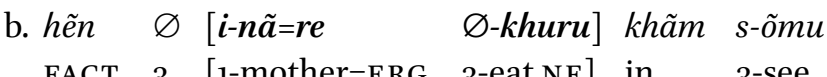
KĨSÊDJÊ
FACT 3 [1-mother=ERG 3 -eat.NF] in 3 -see
'He/she saw my mother eating.' (Nonato 2014: 134)
(lit. 'the eating of it by my mother')

So for Northern Jê, we find in all four languages that the morphological category of nonfinite verb is robust and that the nonfinite verb is always possessed by 
its notional absolutive, leaving the notional A to occur as an oblique, marked by a modern reflex of the genitive postposition $t \varepsilon$. Such parallel constructions, with cognate morphology and identical argument structure patterns, could not have arisen independently in closely related languages due to coincidence; while it is always possible that such a construction could have spread via contact, given the phonological differences between the cognate morphemes, contact is also not a plausible explanation. The Northern Jê nonfinite verb constructions could only be so parallel because they come from a common origin, which Castro Alves (2010) reconstructs to Proto-Northern-Jê.

At this point, the observant reader should note that, for both families, so far we have only reconstructed the morphological forms and/or categories of nonfinite/nominalized verbs and the grammatical treatment of their notional arguments. We have not yet demonstrated that these Proto-Cariban nominalized clauses or the Proto-Northern-Jê nonfinite clauses are in any way related to the nominative-absolutive clauses. The next two sections of the article demonstrate that a cognate to each of these nonfinite/nominalized constructions is found in every single distinct nominative-absolutive clause found so far in any Jê or Cariban language.

However, note that the notional A of these reconstructed nonfinite / nominalized constructions bears a distinctive postposition, which actually does yield an ergative case marker in other innovative constructions in each family (cf. Castro Alves 2010 for Jê; Gildea 1998, 2012 for Cariban). If the same subordinate construction is at the heart of the nominative-absolutive clauses, then either that oblique A must have simply not been realized in the biclausal source constructions or it must have been eliminated as a part of some subsequent change. In Section 5, we explore three biclausal source constructions that maintained the absolutive prefixes on the erstwhile nominalized verbs but, from the outset, arguably did not contain an independent expression of the A in its oblique form; instead, the matrix clause of each construction aligned the notional S and A, creating a nominative category. In Section 6 we explore biclausal source constructions in which the oblique A did occur originally, but was subsequently replaced by a topic pronoun in A and S roles, creating an innovative nominative category.

We now proceed to investigate the clearest cases, those in which a source biclausal construction already contains the nominative-absolutive pattern, just spread between two clauses rather than co-occurring in a single main clause predicate. In each case, the absolutive property of verbal indexation is inherited from 
the source subordinate clause grammar reconstructed in Section 4.2. However, in these specific constructions, the option of expressing the oblique $\mathrm{A}$ in the subordinate clause is not exercised because it is coreferential with the subject of the matrix clause. In these same constructions there is also coreference between the main clause subject and the notional $\mathrm{S}$ of the subordinate clause, however, the morphological realization of the $S$ is as an inalienable possessor, which cannot be suppressed. As such, there is either a lexical or a morphological form expressing $\mathrm{S}$ in both the matrix and the subordinate clauses.

In the most straightforward source construction, found only in the Jê languages, the matrix verb is a transitive verb of completing an action, the subordinate clause is a direct object complement of that verb, and the same participant is inherently the $\mathrm{A}$ of the matrix verb and the $\mathrm{A} / \mathrm{S}$ of the complement clause (Section 5.1). A bit more complicated is the case, found in both families, in which an intransitive main clause takes an adverbial adjunct that contains the subordinate clause structure as the complement of an adposition, with the combination expressing aspectual notions like inceptive and completive, or modal notions like desiderative or intentional. In all these cases, the matrix clause beginner, finisher, desirer or intender is also the $\mathrm{A} / \mathrm{S}$ of the desired/intended action, yielding the necessary coreference conditions to create a nominative pivot (Section 5.2). The third construction is quite idiosyncratic, and is limited to the two Cariban languages: there are actually two morphologically distinct source constructions, each readily reconstructable as independent, which then collapse into a single construction with a suppletive verb inflection and nominative-absolutive alignment (Section 5.3). In all three of these biclausal source constructions, there is an $\mathrm{A} / \mathrm{S}$ pivot that creates a nominative pattern, conditioning both a single form of the S/A pronoun (in the matrix clause) and, in Cariban, main verb agreement with $\mathrm{A} / \mathrm{S}$. When the biclausal construction is reanalyzed as monoclausal, the new construction inherits its nominative patterns - pronominal case and/or auxiliary agreement from the erstwhile matrix clause, while retaining the absolutive indexation from the erstwhile subordinate clause.

\subsection{The Phasal Matrix Verb Source}

This source is well-known from grammaticalization studies, where a phasal verb like 'begin', 'start', 'finish,' or 'stop' takes a nonfinite clause as its $\mathrm{O}$; the A of the matrix phasal verb is always coreferential with the notional A or S of the nonfinite complement clause. After reanalysis, the erstwhile nonfinite verb is the main verb and the erstwhile aspectual verb becomes an aspectual auxiliary. Consider first these examples of cognate nominative-absolutive completive clauses from Canela (7a), Mẽbêngôkre (7b-c), and Kĩsêdjê (7d). 


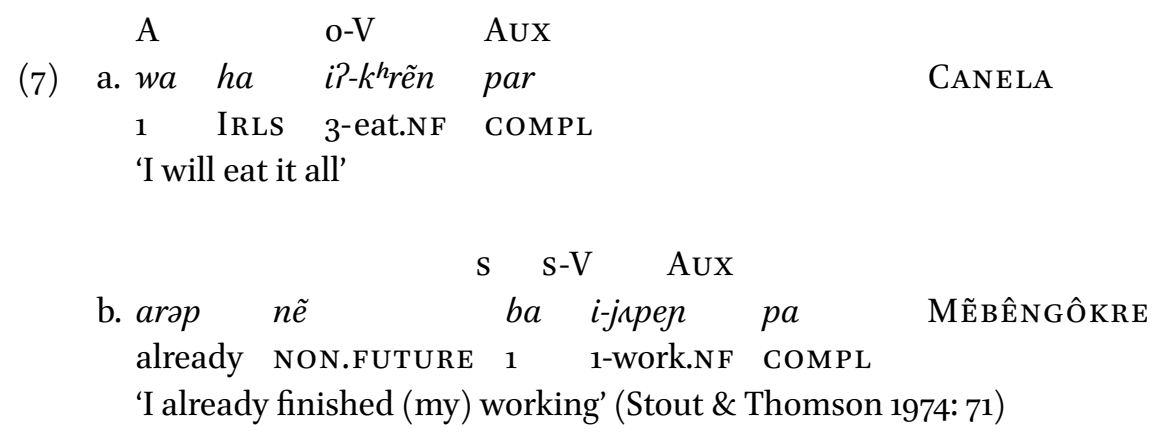

\begin{tabular}{|c|c|c|c|c|}
\hline A & & $o-\mathrm{V}$ & Aux & \\
\hline c. bir & $n \tilde{e}$ & $\varnothing$-krẽn & $p a$ & MẼBÊNGÔKRF \\
\hline Bir & NON.FUTURE & 3-eat.NF & COMPL & \\
\hline
\end{tabular}

\begin{tabular}{|c|c|c|c|c|}
\hline & A & {$[\mathrm{O}$} & V ] AUX & \\
\hline d. $h \tilde{\varepsilon} n$ & wa aro & $i-t-n$ & hwen hwa & KĨSÊDJÊ \\
\hline
\end{tabular}

The following patterns should look familiar by now: in all four examples, the $A$ and $S$ are expressed as unmarked free (pro)nouns preceding the VP, which contains a nonfinite verb form immediately preceded by its absolutive argument, either as a bound prefix $(7 \mathrm{a}-\mathrm{c})$ or a free O NP $(7 \mathrm{~d}) \cdot{ }^{12}$ Synchronically, the completive particle is the last element in the clause; it is analyzed as a particle because it is able to occur after the main verb, which usually is the final element of a clause, and because it takes a single invariant form.

In only one language, Kĩsêdjê, have we found a lexical verb that is cognate to this particle, the verb hwa 'kill, finish', used in the sense of 'kill all of' (8). Unfortunately, there is only a single example, and so we do not have evidence of a nonfinite form something like hwar 'finish.NF'.13

12 We added the gloss ' $\mathrm{NF}$ ' to the non-finite form in (7c), which Stout \& Thompson apparently overlooked.

13 In Canela the form partu is attested in alternation with the simple form $p a$ - it is speculative, but not impossible, to imagine that this alternant contains an archaic reflex of a nonfinite form par followed by some unidentified element $=t u$. 
(8)
nuks-n
kukwəy hwa
KĨSÊDJÊ
Nháko-Top monkey kill/finish
'Nháko finished/killed the monkeys (until they were all gone)'

(Santos 1997: 92)

Despite the absence of this form as a lexical verb in the other languages, it is relatively easy to find examples of complement-taking verbs with phasal meanings, such as the modern examples from Canela with the main verbs $i k u$ 'stop' ( $9 \mathrm{a}-\mathrm{c})$. The monoclausal main verb use of $i k u$ is illustrated in (9a), where it is preceded by the $\mathrm{O}$ pзrkre 'boat', and its use as the matrix verb of a biclausal phasal verb construction is illustrated in $(9 b-c)$. Note that the grammar of the two biclausal constructions is exactly parallel to that of the nominativeabsolutive clauses: the subject of the transitive phasal matrix verb occurs first as an unmarked pronoun; the phasal matrix verb is final, preceded by its object, the nonfinite verb plus its absolutive argument ( $\mathrm{S}$ in (9b), $\mathrm{O}$ in (9c)). The absolutive is the same obligatory possessor that we reconstruct in Section 4, expressed either as a possessive prefix ( $9 b)$ or a free noun possessor immediately preceding the nonfinite verb (9c). Given the condition of coreference with the matrix clause $\mathrm{A}$, the oblique notional $\mathrm{A}$ of the nonfinite verb is not (and cannot be) expressed. Thus, the visible argument structure of the entire construction is as follows: The notional A of the nonfinite verb is expressed only via the explicit $A$ of the phasal matrix verb, the notional $\mathrm{O}$ of the nonfinite verb is expressed only as the possessor of the nonfinite verb, and the notional $S$ of the nonfinite verb is expressed twice, once as the A of the phasal matrix verb and once as the obligatory possessive prefix on the intransitive nonfinite verb.

(9) Canela aspectual verb example:
A $\quad\left[\begin{array}{ll}\mathrm{N}_{\mathrm{O}} & \mathrm{V}_{\mathrm{TR}}\end{array}\right]_{\mathrm{VP}}$

a. wa pзrkre j-iku

CANELA

1 boat RP-stop

'I stop [the boat].'
A
$\left[[\text { POsSR-V.NF }]_{\mathrm{O}} \quad \mathrm{V}_{\mathrm{TR}}\right]_{\mathrm{VP}}$
b. ka ha [a-j-зpәn]
j-iku
CANELA
2 IRLS 2-RP-eat
RP-finish

lit. 'you will stop [your ${ }_{i}$ eating] ' (Castro Alves 2004: 134)

\begin{tabular}{|c|c|c|c|c|}
\hline A & & {$\left[[\text { PossR V.NF }]_{\mathrm{O}}\right.$} & $\left.\mathrm{V}_{\mathrm{TR}}\right]_{\mathrm{VP}}$ & \\
\hline c. $k a$ & ha & {$\left[\begin{array}{ll}h \tilde{\imath} & k u r\end{array}\right]$} & $j-i k u$ & CANELA \\
\hline 2 & IRLS & eat.NF & RP-stop & \\
\hline
\end{tabular}


At this point, we assert that this combination of cognate morphology, order of elements, and argument structure patterns could not have arisen via chance. As seen in examples $(7 \mathrm{a}-\mathrm{d})$, the grammar of the nominative-absolutive completive clause is identical across the three northern Jê languages, and the postverbal particle is still attested as a lexical verb meaning 'kill/finish' in one of these languages (8). As seen in examples $(9 \mathrm{~b}-\mathrm{c})$, the grammar of biclausal constructions with phasal matrix verbs is virtually identical to the nominativeabsolutive completive clause, the only difference being the lexical status of the final element, a transitive verb in (9a-b), but an aspectual particle in (7a-d). It is straightforward to make the argument that the constructions in (7) are too similar in both form and meaning for the parallels to have arisen by chance, so we must posit that they have arisen from a common source. The parallels between the grammar of (7) and the synchronically biclausal phasal construction in $(9 \mathrm{~b}-\mathrm{c})$ are also too similar to be due to chance, suggesting parallel source constructions. The completive particle is cognate to a lexical verb (8) and it occurs in exactly the same clausal location as the phasal matrix verb in ( $9 \mathrm{a}-\mathrm{b})$. As such, we now have sufficient evidence to posit a biclausal proto-construction (10), parallel to that in $(9 \mathrm{a}-\mathrm{b})$, which gave rise to the modern completive constructions in (7).

The example in (10a) is exactly parallel to the one in $(9 b)$, with the nonfinite intransitive verb i-japen 'my working' occurring as the object complement of $p a$ 'finish'. Although the 'finisher' and the 'worker' in both clauses is the same referent, the prefix in the subordinate clause cannot be deleted or suppressed due to coreference because the nonfinite verb is obligatorily possessed. In $(10 b)$, parallel to (9c), the nonfinite transitive verb $i{ }^{2}-k^{h} r e \tilde{n}$ 'its eating' is the object complement of $p a$ 'finish'. The oblique notional A argument of the nonfinite clause does not occur due to the coreference with the A of the main clause verb. The result is a clause in which the sole reference to the A of both verbs is the unmarked pronoun that belongs grammatically to the main verb 'finish', whereas the possessive prefix on the transitive nonfinite verb references only its O. We repeat the examples in English calques in (11a-b), to illustrate the coreference conditions in a form that will be more familiar to most readers.

(10) A reconstructed source for the completive clause in Proto-Northern Jê

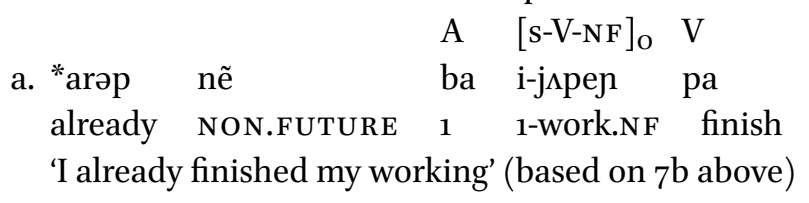



A $\quad[\mathrm{o}-\mathrm{V}-\mathrm{NF}]_{\mathrm{o}} \quad \mathrm{V}$
b. *wa ha i?-krẽn par
$1 \quad$ IRLS 3-eat.NF finish
'I will finish eating it' (lit. 'its eating') (based on 7a above)

$\begin{array}{lll}\text { (11) } & \text { a. } \mathrm{I}_{i} \text { finished }\left[\mathrm{my}_{i} \text { working }\right]_{\mathrm{o}} & \text { (matrix } \mathrm{A}=\text { Sbrd } \mathrm{S} \text {; Sbrd possessor }=\mathrm{S}) \\ \text { b. } \mathrm{I}_{i} \text { will finish }\left[\varnothing_{i} \text { its } \text { eating }_{\mathrm{o}} \text { eatix }\right. & \text { (matrix } \mathrm{A}=\text { Sbrd A; Sbrd possessor }=\mathrm{O})\end{array}$

After reanalysis, the argument structure has both a nominative subject $(<\mathrm{A}$ of the matrix complement-taking verb) and an absolutive verbal prefix (< obligatory possessive prefix on the nonfinite $\mathrm{V}$ ); the matrix transitive verb becomes the auxiliary particle, $p a$, and the erstwhile subordinate verb - still in its morphologically nonfinite form - becomes the new main verb. The combined argument structures in the source clearly provide both the nominative S/A and absolutive S/O patterns, so after reanalysis, no further adjustment is necessary to create the nominative-absolutive alignment.

As a postscript to this section, we present the less consistent cognate construction in Apinajé as a likely case of constructional innovation in progress. Oliveira (2005) does not explicitly describe the grammar of the completive construction, but her dictionary in Appendix C lists the form $p a$ 'CONCLUSIVE; COMPLETIVE', and there are 39 examples scattered throughout the grammar and the appended texts. Of these, 11 examples contain five transitive verbs, two intransitive verbs, and four descriptive verbs that have no morphological distinction between finite and nonfinite. Also, four examples contain three verbs (one of which occurs twice) for which Oliveira does not indicate whether the form is finite or nonfinite and they occur nowhere else in the work. Of the remaining 24 examples, 13 examples contain eight transitive verbs (two of which occur twice) and three intransitive verbs in the expected cognate nonfinite form, accompanied by the nominative-absolutive grammar, as seen in (12a-b).

\begin{tabular}{|c|c|c|c|c|c|c|c|}
\hline & $n \tilde{e}$ & abri & pre & & $\begin{array}{l}\text { s-V.NF } \\
i-j-a k r \varepsilon n\end{array}$ & $\begin{array}{l}\text { AUX } \\
p a\end{array}$ & APINAJÉ \\
\hline (12) & $\begin{aligned} \text { a. } & n e \\
& \mathrm{CNJ}\end{aligned}$ & $\begin{array}{l}\text { abrl } \\
\text { then }\end{array}$ & $\begin{array}{l}\text { pre } \\
\text { PAST }\end{array}$ & $\begin{array}{l}m e \\
\mathrm{PL}\end{array}$ & $\begin{array}{l}\text { l-J-akren } \\
\text { 1-RP-go.by }\end{array}$ & $\begin{array}{l}p a \\
\text { CNCL }\end{array}$ & APINAJE \\
\hline
\end{tabular}
A $O$ V.NF AUX
b. kot paj kaga n-ipetf pa ri kstmã apku APINAJÉ IRLS 1.IRLS mark RP-make COMPL LOC still eat.INTR 'I will eat upon/when I have finished studying' (Oliveira 2005: 291) 
However, the remaining 11 examples are surprising in that the main verb occurs in the finite form instead of the expected nonfinite form preceding $p a$ 'COMPL'. Ten of these unexpected examples are of transitive verbs and only one is an intransitive verb. We illustrate these surprising patterns via the examples in (13a-b): in (13a), the finite form of the intransitive verb $t \int a$ 'stand' precedes the particle $p a$ and in (13b), the finite form of the transitive verbs $k r \tilde{e}$ 'eat' and $t i \iota$ 'put' each precede the particle $p a$.

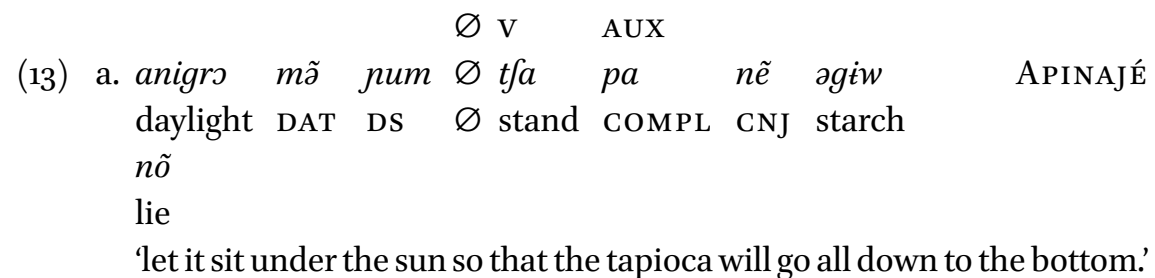

(Oliveira 2005: 355 )

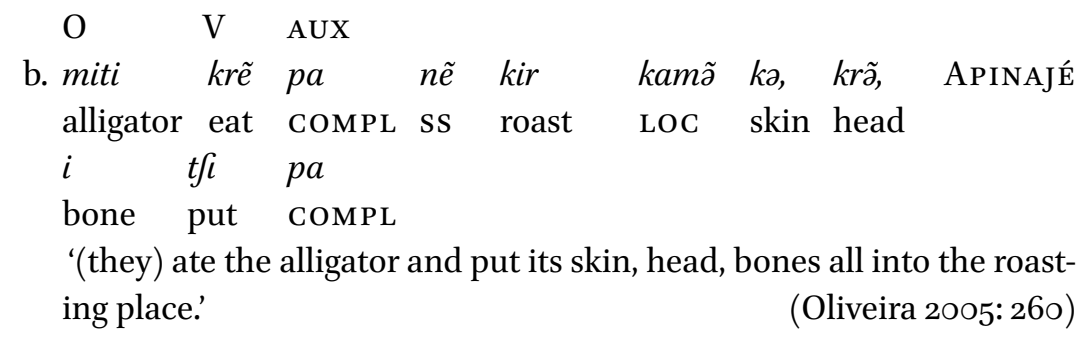

At this point, we must give some historical account of the completive construction in Apinajé, which has main verbs preceding $p a$ in both the expected nonfinite form and in the surprising finite form. We can imagine three possible theories, of which the only one that seems plausible departs from our reconstruction above. First, we might posit a proto completive construction in which the main verb was finite; in this case, the other three Northern Jê languages would have entirely replaced the finite forms with nonfinite forms, and Apinajé has nearly completed this replacement as well, but still retains the original finite form in some (currently undefined) contexts. Second, we might posit a proto completive construction in which the main verb could be either finite or nonfinite, as currently attested in Apinajé; in this case, Apinajê would conserve the proto system and the other three languages would have converted the subset of finite forms to nonfinite. We find both scenarios unlikely because the completive construction is clearly a type of main clause in the synchronic grammar of all four languages, with no obvious drift towards becoming subordinate; as such, we see no motive for the spontaneous replacement of the finite form with a nonfinite form. 
The only plausible hypothesis is that the matrix verb * $p a$ 'finish' became the completive particle $p a$ already by Proto-Northern Jê (and perhaps even earlier, although testing this hypothesis would require expanding the comparative data to include the other branches of the family); the nonfinite form of the main verb and its accompanying nominative-absolutive argument structure were retained without change in Canela, Mẽbêngôkre, and Kĩsêdjê. In Apinajé, a subset of the completive clauses continues to conserve the proto-structure, but a new construction has arisen in which a finite verb may now occur preceding pa 'COM PL'. Our post hoc explanation for this innovation is that (i) speakers no longer think of $p a$ as a verb (presumably this would be true in all four languages) and (ii) they have subconsciously drawn an analogy between the nonfinite main verbs of this construction and the finite main verbs that occur in many other constructions. This condition of analogy then allows the extension of the finite verb forms (with their accompanying argument structure) into the completive construction, creating a new completive construction that we assume must be distinct in use from the original construction, whether semantically, pragmatically, or stylistically. Obviously, this would be a fascinating topic for further synchronic research in Apinajé.

\subsection{The Adverbial Predicate Sources}

Our second source is also well-known from grammaticalization studies, in which the matrix clause predicates a location or other adverbial property of the subject, and in which the adverbial predicate consists of the subordinate (nonfinite / nominalized) clause embedded in a postpositional phrase. This is a common source of progressives (Heine 1994; Bybee et al. 1994), and is implicated here in the Panare DESIDERATIVE and FUtURe, as well as the northern Jê PROGRESSIVE, CONTINUATIVE, and INGRESSIVE.

\subsubsection{In Northern Gê}

We begin with the progressives, which are based on two models. The first model, found in Canela $(14 a-c)$, Apinajé $(15 a-b)$ and Mẽbêngôkre (16a-b) takes an intransitive main verb of motion, $m \tilde{o} / m \tilde{s}$ 'go', preceded by the cognate form to 'PREVERB (PV)' (Canela), o 'INSTR' (Mẽbêngôkre), or o 'do' (Apinajé). Note the expected argument structure: the main clause $\mathrm{S}$ and $\mathrm{A}$ are not required to occur (cf. 14a, 15b), but if they do, they occur early in the clause as free pronouns (14b, 15a, 16b) or as unmarked nouns (16a). The main verb appears in its nonfinite form, preceded by either the absolutive prefix (14a-b, $15 \mathrm{a}-\mathrm{b}$, $16 a-b)$ or a free NP O (14c). 


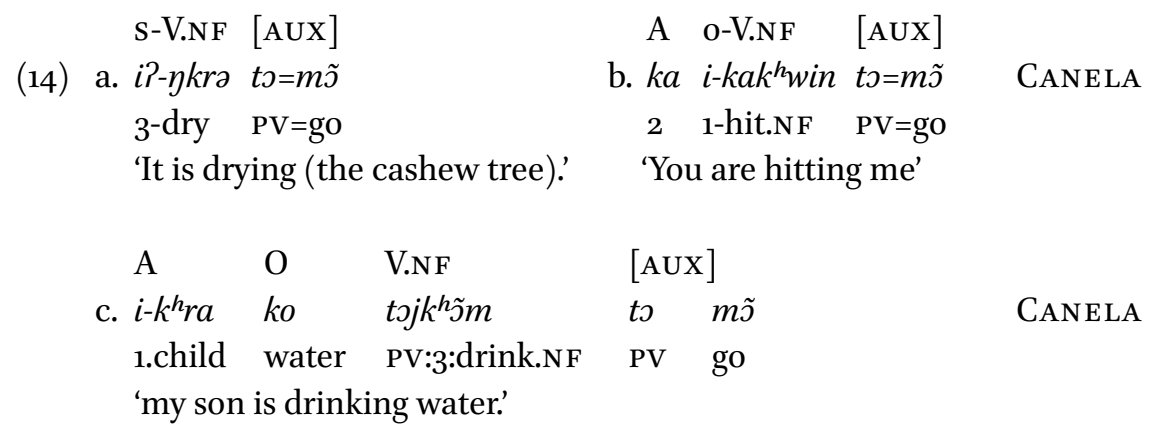

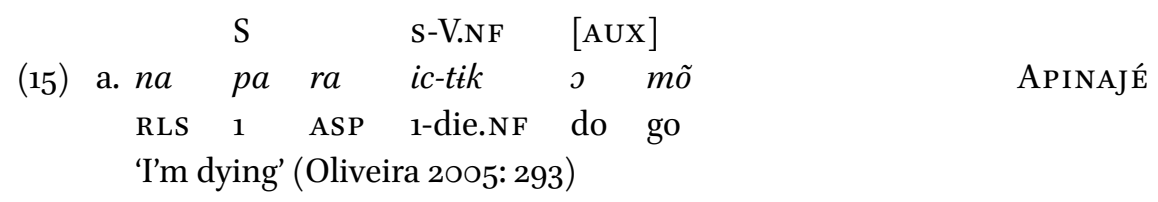
S-V.NF
[AUX]
b. $n a \quad r a \quad \varnothing-k n \quad$ o $m \tilde{o}$
ApinajÉ
RLS ASP 3-mature.NF do go
'It's getting ripe already.' (Oliveira 2005: 294)
A o-V.NF [AUX]
(16) a. bir nẽ $\varnothing$-krẽn o mõ
Bir N.FUT 3-eat.NF do go
'Bir is eating it (moving)' (Stout \& Thomson 1974: 71)

MẼBÊNGÔKRE
A o-V.NF
[AUX]
$\begin{array}{cll}\text { b. } b a & k w \tilde{u} n & \jmath=m \tilde{a} \\ \text { 1NOM } & \text { 3.break.SG.NF } & \text { INSTR=go.PL }\end{array}$
MẼBÊNGÔKRE
'I am breaking it' (Salanova 2007: 55)

The synchronic analysis of the auxiliary complex differs between the languages not because the grammatical behavior is different, but because three different analyses have been proposed for the cognate form $t$ / / preceding $m \tilde{o} /$ $m \tilde{o}$ 'go'. In all three languages, the existing descriptions distinguish between the instrumental postposition $t \mathrm{~s} / \mathrm{s}$ 'INSTR' and the homophonous preverbal causativizer to/s 'CAUs'. To these two meanings, Castro Alves (2015) adds the homophonous form to 'PREVERB (PV)' and both Stout \& Thomson (1974) and Oliveira (2005: 415) consider this specific construction to contain the homophonous transitive verb o 'do', which immediately precedes other verbs (such as $m \tilde{o}$ 'go' in these examples) in a serial verb sequence. Regardless of the preferred 
synchronic analysis, looking at these examples, the similarity in morphological form and syntactic location cannot be an accident - these constructions clearly all must be modern reflexes of a single source construction.

We suggest that this historical source construction most likely contained its invariant morphemes with the consistent values that they currently show when not combined in this construction: the main verb must have been $m \tilde{\jmath}$ 'go', the form 0 must have been the instrumental/locative postposition, the nonfinite verb form must have been the object of this postposition, and the unmarked subject (pro)noun must have been the subject of the verb $m \tilde{s}$ 'go'. This source is modeled in $(17 \mathrm{a}-\mathrm{b})$, giving the etymological analysis of the Canela examples in (14a-b). Note that once again, given the condition of coreference between the $S$ of the matrix clause and the notional A of the nonfinite verb, this notional A does not occur explicitly, thereby leaving the superordinate $S$ as the only grammatical form that references the notional A.

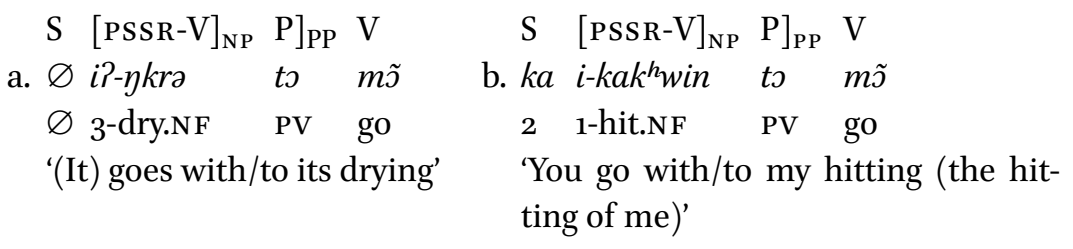

Clearly, this has become a new construction (in the sense of Goldberg 2006) in both Apinajé and Canela in that the semantics of the construction are not derivable from the semantics of the component words \& morphemes: specifically, there is no longer any element of translational movement in either the Canela or the Apinajé examples, and the instrumental/locative semantics are completely absent in all three languages. After reanalysis, the argument structure has both a nominative subject ( $<\mathrm{S}$ of the matrix verb of motion) and an absolutive verbal prefix (< obligatory possessive prefix); the matrix intransitive verb becomes the auxiliary $m \tilde{s}$, and the erstwhile subordinate verb - still in its morphologically nonfinite form - becomes the new main verb. In the source, the argument structure of the matrix verb provides the nominative S/A patterns and the argument structure of the nonfinite verb provides the absolutive $\mathrm{S} / \mathrm{O}$ pattern, so after reanalysis, no further adjustment is necessary to create the nominative-absolutive alignment. ${ }^{14}$

14 The same structure except with a different verb of motion, $t \tilde{\varepsilon}$ 'go', gives rise to an alternative progressive in both Canela and Kĩsêdjê, illustrated in passing in Gildea \& Castro Alves (2010: 177, 185). 
We turn now to the continuative/progressive constructions based on posture verbs, found in all four languages. We illustrate this with the auxiliary verbs $t a / t \int a / d z a$ 'be standing' (18) and $j \tilde{t}$ 'be sitting' (19). In the now-familiar pattern, the nominative argument is expressed via an unmarked noun or pronoun occurring in initial position (although it can be preceded by initial TAM particles, cf. 19a, d, and also by left-dislocated topic pronouns, cf. 19c), whereas the absolutive argument is either a free noun $\mathrm{O}(18 \mathrm{~b}, \mathrm{~d}, 19 \mathrm{c}-\mathrm{d})$ or an absolutive prefix on the verb (18a, c, 19a-b).

(18) Based on the auxiliary $t a / t f a / d z a$ 'be standing'
$\mathrm{S}$ S-V.NF [ AUX ]
CAnela
a. $w a$ i-t fwar $\quad t s=t f a$
1 1-bathe.NF $\mathrm{PV}=$ stand
'I am bathing myself'

$\begin{array}{lll}\text { A } & {[\mathrm{O}} & \text { V.NF }] \quad[\mathrm{AUX}] \quad \text { KĩsêDJÊ }\end{array}$

b. kaomi ra aygro pĩri mã to ta Kaomi sM pig kill.nF ? do be.standing

'Kaomi is killing the pig' (Santos 1997:514) $)^{15}$
S S-V.NF $\quad[$ AUX $] \quad$ MẼBÊNGÔKRE
c. mẽnire nẽ $\varnothing$-toro $0 \quad d z a$
woman RLS 3-dance.NF do be.standing
'The woman is dancing' (Castro Alves \& Reis Silva 2007)
A $\left[\begin{array}{ll}\mathrm{O} & \mathrm{V} . \mathrm{NF}\end{array}\right]$ [AUX $]$
MẼBÊNGÔKRE
d. ga tzp krẽn o dza
2 fish eat.NF do be.standing
'You are eating fish (standing)' (Castro Alves \& Reis Silva 2007)

(19) Based on the auxiliary $\mu \tilde{t}$ 'be sitting'
[Aux]
KĨSÊDJÊ
a. hẽn wa i-mbara ro $n \tilde{t}$
ASP 1 1-cry.NF do be.sitting
'I am crying' (Santos 1997: 87)

\footnotetext{
15 We maintain Santos' gloss 'SM' (Subject Marker) on the particle $r a$, but we question this analysis (Section 6.3). Its similarity to the demonstrative pronoun $t a$ in other northern Jê languages suggests a possible analysis as a definite marker.
} 

S $\mathrm{s}-\mathrm{V}$
b. mẽnire nẽ $\varnothing$-tor [Aux]
MẼBÊNGÔKRE woman RLS 3-dance.NF do be.sitting 'The woman is dancing (sitting)' (Castro Alves \& Reis Silva 2007)
Top A $\left[\begin{array}{ll}\mathrm{O} & \mathrm{V}\end{array}\right]$ [Aux] KĨSÊDJÊ
c. $p a-n$ wa tep kuru ro jiz 1-Top 1 fish eat.NF do be.sitting 'I who am eating the fish' (Santos 1999: 232) ${ }^{16}$

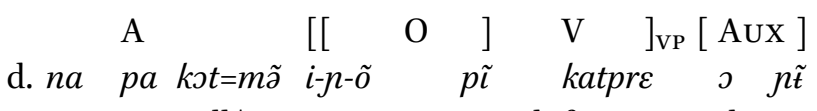
RLS 1 still/yet 1-RP-GEN wood fasten.NF do sit
'I'm still fastening my wood' (Oliveira 2005: 294)
A O-V.NF [AUX]
CANEla
$\begin{array}{lll}\text { e. humre } & i \text { l- }^{h} r \tilde{\varepsilon} n & t 0=h \tilde{t} r \\ \text { man } & \text { 3-eat.NF } & \mathrm{PV}=\text { be.sitting }\end{array}$
'The man is eating (something) (sitting)'

Once again, we reconstruct the sources of these clause types beginning with the morphological cognates: clearly the auxiliaries are cognate with the main verbs for 'stand' and 'sit', plus the postposition to/ro/o 'INSTRUMENTAL/ LOCATIVE' with its object, the nonfinite form of the main verb possessed by its absolutive argument. In the source construction, the subject of the posture verb is coreferential with the notional S/A of the nonfinite verb, leading to coreference with the obligatory notional $S$ possessor of the intransitive nonfinite verb, but conditioning the absence of the optional oblique notional A of the transitive nonfinite verb. After reanalysis, the former $S$ of the intransitive posture matrix verb becomes the S/A of the innovative clause; the former possessor of the nonfinite verb becomes absolutive indexation on the main verb. While the source is clear, in this construction, the semantic evidence for reanalysis is somewhat scant, given that the semantics of the entire construction

16 The translation is a calque of the Portuguese translation given by Santos: 'Eu que estou comendo o peixe.' In colloquial Brazilian Portuguese, this construction is used to place focus on the subject of a clause, a meaning consistent with the initial topic-marked pronoun, which is coreferential with the following A pronoun. 
could be derived by combining the semantics of the component morphemes (i.e., the translations indicate that the subject is understood as being in the posture indicated by the verb, that is, seated or standing, while doing the action that is in progress).

\subsubsection{Predicate Adverbials in the Cariban Family}

In the Cariban family, predicative adverbials have given rise to the future tense in both Panare and Yukpa and to the desiderative mood in Panare, each with the same nominative-absolutive argument structure. Consider first the future tense, as seen in (20a-b). In (20a), the intransitive main verb arikt 'end' comes first, followed by the copular auxiliary and the unmarked $S$ pronoun. The verb bears the future tense suffix -sejpa, the intransitive verb class marker $w$ - ' $\mathrm{S}_{\mathrm{A}}$ ', and the third person absolutive prefix $y$ - ' 3 '; the nonverbal auxiliary agrees with the third person $\mathrm{S}$ for animacy. In $(2 \mathrm{ob})$, the transitive main verb ama 'throw' comes first, followed by the unmarked free pronoun A yu 'isG'. This verb also bears the future suffix -sejpa plus the third person absolutive prefix $y$ - ' 3 '. It is standard for there to be no copula with first and second person subjects, so the absence of an auxiliary in (2ob) is not surprising.

\begin{tabular}{|c|c|c|c|c|c|}
\hline \multirow{5}{*}{$(20)$} & \multirow{2}{*}{$\begin{array}{l}\text { s-V } \\
\text { a. yuri'chejpa }\end{array}$} & S.AUX S & $0-\mathrm{V}$ & \multicolumn{2}{|l|}{ A } \\
\hline & & kё’ kamënton & b. yamasejpa & $y u$ & PANARE \\
\hline & y-w-ariki-sejpa & kamënton & y-ama-sejpa & yu & \\
\hline & 3-INTR-end-FUT & 3.COP they & 3-throw-FUT & 1SG & \\
\hline & $\begin{array}{l}\text { 'they (= their fam } \\
\text { finished.' (Mattéi }\end{array}$ & $\begin{array}{l}\text { ily line) will be } \\
\text { Muller 1994: } 21 \text { ) }\end{array}$ & $\begin{array}{l}\text { 'I will throw i } \\
\text { (Mattéi Mull }\end{array}$ & & :xxxii) \\
\hline
\end{tabular}

To identify the source grammar of the Panare future tense, we first identify the individual morphemes in the construction. The auxiliary is clearly identical to the nonverbal copula (cf. Gildea 1993a-b) and the prefixes on the main verb are those expected on a nominalization: the verb class marker $w$ - 'INTR' is only found on nominalizations or participles in multiple Cariban languages (cf. Meira 2000: 205-208) and the absolutive person prefixes are identical to the possessive prefixes. The suffix -se'pa represents three etymological morphemes. The first, *-cett 'NOMINALIZER' (Gildea 2003:17) has only a few reflexes in modern Cariban languages: only in Tamanakuit is it attested as a nominalizer without additional suffixal material; it is attested preceding the adverbializing suffix - $p e$ 'ESSIVE' in the Tamanaku adverbial suffix -chetpe 'PURPOSIVE' (Gilij 1965[1780-1784]/III: 30) and the Panare medial clause suffix -sehpe 'HC. 
AGT.SEQ' ('high participant continuity, agent-oriented, sequential', Payne \& Payne 2013: 404-405). ${ }^{17}$

The composite suffix *-ceti-pe is also attested as being nominalized by means of the suffix - ano 'NZR', which causes the final vowel of - pe to shift to $a$ : Tamanaku y-are-chet-pa-no 'one with the purpose of taking' (Gilij 1965[17801784]/III: 264). The cognate nominalized form in Panare has undergone two regular phonological changes: first, final vowels of nouns generally delete, creating consonant-final forms (Gildea 2003:18-20); second, the nasal component of the nominalizing suffix is lost, leaving the vowel shift as the only morphological indication of nominal versus adverbial status, As such, a final $-e$ indicates adverbial forms and a final - $a$ indicates nominal forms. ${ }^{18}$ Thus, the Panare suffix -sehpa 'FUTURE' represents the reduction of an earlier form *-ceti-pa-no 'one with the purpose of V-ing'.

With all these morphological cognates in hand, it is relatively straightforward to combine them into the source construction for the Panare future: the matrix clause was a predicate nominal construction with a nominalization as the predicate noun. This predicate nominalization has as its core a verb root; this root is nominalized, making it obligatorily possessed by the notional absolutive. This possessed nominalization bears the essive suffix (itself a reduced form of the reconstructable essive postposition), resulting in a form that is attested synchronically as the medial/adverbial suffix -sehpe. This adverbial form is itself nominalized, creating a form with an etymological meaning something like 'one who is with/like the purpose/destiny of doing the act described by V', or more briefly, 'one that is destined to V'. Such a meaning is eminently compatible with the interpretation that the individual will undertake the act in the future, so both the form and the meaning of the future tense construction in Panare follow naturally from the forms and meanings in the cognate nonfinite

17 An anonymous reviewer suggests that our *-ceti could also be cognate with *-keti 'S.NZR', another nominalizer with very limited distribution in the family (attested in only Tiriyó, Apalaí, and Makushi). We hope to consider this possibility more carefully in future research, as it would be most welcome to identify cognates to this form outside the inner circle of Venezuelan languages in which it is currently found.

18 This same vowel alternation characterizes adverbial versus nominalized forms of other adverbializing suffixes, including -ke 'PROPRIETIVE', and -re/-ye 'ADVERBIAL'. Payne \& Payne (2013: 124-125) illustrate these patterns, but assume that the nominal $a$ form is basic, from which the $e$ form adverb is derived (although they acknowledge the alternate possibility on p. 118). Mattéi Muller (2007) argues that, for certain verbal suffixes, this vowel alternation has become an indicator of a temporal and epistemic distinction, with the $e$ forms generally indicating less certain / temporally stable meanings and the $a$ forms indicating more certain / temporally stable meanings. 
constructions attested in the other languages. This proposed etymological analysis is laid out in $(21 a-b)$.

$$
\left[\left[[\text { PSSR-V-NZR }]_{\mathrm{NP}} \mathrm{P}\right]_{\mathrm{PP}}-\mathrm{NZR}\right]_{\mathrm{NP}} \text { s.COP } \quad \mathrm{S}
$$

$\begin{array}{lll}\text { a. yurichejpa } & k \ddot{e} & \text { kamënton } \\ \mathrm{y} \text {-w-ariki-sej-pe-a } & \text { kë' } & \text { kamënton } \\ \text { 3-S } \mathrm{S}_{\mathrm{A}} \text {-end-NZR-ATTR-NZR } & \text { 3.COP } & \text { they }\end{array}$

'they (= their family line) is one that is like destined to end.'

(Mattéi Muller 1994: 21)

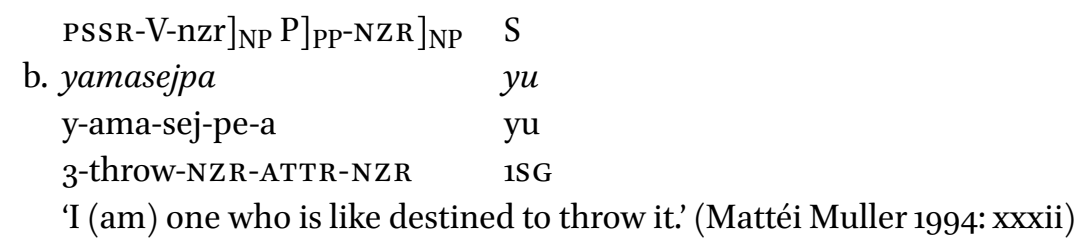

Following the reanalysis, we have the familiar matrix clause $\mathrm{S}>$ nominative argument and subordinate clause possessor $>$ absolutive argument, with the copula (when one occurs) agreeing with the former matrix clause $\mathrm{S}>$ nominative.

A similarly complex set of morphemes coalesces into the desiderative suffix, which is shown in (22) to occur in a standard nominative-absolutive construction.

\begin{tabular}{|c|c|c|c|}
\hline & $s-V$ & \multicolumn{2}{|l|}{ S-AUX } \\
\hline & a. witëjtëpa & waasin & Panare \\
\hline & $\varnothing$-w-të-jtë-pa & \\
\hline & 1-S A $_{\mathrm{A}}$-gO-DESID-DUR & \multicolumn{2}{|l|}{ IS-AUX.PAST-REL } \\
\hline & \multicolumn{3}{|c|}{ 'I wanted to go.' (Mattéi Muller 1994: 76) } \\
\hline & $o-\mathrm{V}$ & A.Aux A & \multirow{3}{*}{ Panare } \\
\hline & b. atyajtépe & këj kën & \\
\hline & a-tya-jté-pe & kën & \\
\hline & 2-hear-DESID-TEMP & 3.COP 3.ANIM & \\
\hline
\end{tabular}

There are actually several allomorphs of the Panare desiderative whose synchronic distribution (and possible meaning difference) remain poorly understood: -jtë, -jtëpa, -jtëpe 'DEsIDERATIVE' (from Mattéi Muller 1994) and jtépe, -jtépi, -jtépa 'Desiderative' (from Payne \& Payne 2013: 217-220). The fourth set of allomorphs, -jtë'ka/-jtéka 'Negative.Desiderative' (from Mattéi 
Muller 1994 and Payne \& Payne 2013, respectively) is clearly negative. There appear to be four distinct etymological units here, with variation in the pronunciation of the first and final vowels perhaps representing dialectal variation: the root of every variant of the desiderative suffix is -jtë/-jté 'one that wants', which is attested as occurring alone (in Mattéi Muller's corpus), or (in both sources) followed by the essive suffix - $p e /-p i$, the nominalized essive suffix - $p a$, or the negative suffix -'ka.

The multiplicity of forms makes it somewhat more difficult to reconstruct the actual morphology of the source construction, not least because only two of these segmented forms, $-p e$ and - $p a$, have readily recognizable cognates in other Cariban languages. That said, both -jtë/-jté and -'ka might be recognizable as cognate to attested forms given irregular syllable reduction in the Panare reflexes (common in contexts of grammaticalization and also not particularly unusual in Panare).

First, the desiderative root suffix, $-j t \ddot{e}$, could come from a reduction of either the Proto-Cariban desiderative postposition *te (> Pan. se) plus the (lexically conditioned) allomorph of the nominalizer *-to (> Panare - $t \ddot{e})$, or it could come from a reduction of the verbal root $p i$ 'want', attested in other Venezuelan languages, plus the agentive adverbializer *të, itself followed by the nominalizer *-no, a combination which would regularly become -to in Panare. ${ }^{19}$ In favor of the first hypothesis are the cognates sa-to (Apalaí; Koehn \& Koehn 1986: 96), $x a$-tî (Waiwai; Hawkins 1998: 96), and sa-to (Tiriyó; Meira 1999: 189). ${ }^{20}$

The reduction of the penultimate syllable would be irregular because the nominalizer should have conditioned lowering of the postposition vowel to $a$, which generally is not a reducing vowel: $-s a-t \ddot{e}>-s t \ddot{e}>-j t \ddot{\text { e}}$. The correspondence in the nominalizing suffix of Tiriyó $o$ to Panare $\ddot{e}$ is also irregular, but its plausibility is enhanced by the irregular correspondence with Waiwai $\hat{\imath}$ as well. Against the first hypothesis is the fact that nominalized forms of the desiderative postposition are not attested in languages more closely related to Panare, nor is it common for the vowel $a$ to delete in reducing syllables. In favor of the second hypothesis, the verb $p i$ 'want' is attested nearby to Panare, the adverbializing suffix is attested in Panare, and the loss of the nominalizing suffix *-no (after changing word class and the preceding vowel) is also well attested in Panare. Against the second hypothesis is the absence of a motivation for the composite form *-jto >-jtë/-jte. At this point, we are not convinced that either hypothesis is compelling, but either is marginally plausible and both have the

\footnotetext{
19 Our thanks to an anonymous reviewer for this suggestion.

20 In Tiriyó, the desiderative postposition also accepts the non-cognate nominalizer $-n(o)$, as in -sa-n (Meira 1999: 189), and only a reflex of *-no is found nominalizing $s e(>s a)$ in Kari'na sa-n (Hoff 1968: 314) and Wayana sa-no (Tavares 2005: 171).
} 
benefit of providing the argument structure that becomes the nominativeabsolutive pattern in the resultant desiderative clause.

The final suffix -'ka 'negative' is also an inflectional suffix in Panare (Payne \& Payne 2013: 229-230), but the only plausible cognate forms from other Cariban languages are in the phrasal negative particle *taike 'not' ${ }_{1}$ (Proto-Taranoan; Meira 2000: 104-105) and taki 'NEG' (Katxuyana, Gildea's field notes), which presumably would have been itself nominalized to form taka 'one that is not'; after affixation, the first syllable would then have idiosyncratically reduced to produce -'ka. The attested forms and their proposed etymologies are all listed in (23).
(23) * se-ato
$>\quad-j t \ddot{e}$
'one that wants'
*se-ato-pe
$>\quad-j t \ddot{e}-p e /-j t e ́-p e$
'like one that wants'
*se-ato-pe-ano
$>\quad-j t \ddot{e}-p a /-j t e ́-p a$
'one that is like one that wants'
*se-ato-take-ano
$>\quad$ jtë-'ka/-jté-'ka
'one that does not want'

Although there is much more descriptive and comparative work to be done before we can be certain about the details of the ultimate sources for these specific morphemes, we know that the argument structure in the source was identical to that of the future tense: the $\mathrm{S}$ of the (copular) nonverbal predicate was coreferential with the A/S of the embedded (nonfinite) clause, and as such, the oblique A of the subordinate clause did not occur; the embedded clause was possessed by its absolutive argument. To get the flavor of this construction, consider the English calques in $(24 \mathrm{~b}-\mathrm{c})$ :
(24) a. I am [like [one who wants [
b. $\mathrm{I}_{i}$ am [like [one who wants [
'I want to walk'
c. $\mathrm{I}_{i}$ am [like [one who wants $\left[\varnothing_{i}\right.$ the book's writing] $\left.]\right]_{\mathrm{PP}}>$ 'I want to write the book'

In (24b) the subject of the matrix copula is coreferential with the notional S of the subordinate clause, but the subordinate $S$ also must occur, like a resumptive pronoun, as the obligatory possessor of the nominalized intransitive verb. In (24c), the subject of the matrix copula is coreferential with the notional A of the subordinate clause, but as that $\mathrm{A}$ is an optional oblique, it is readily elided, leaving the notional $\mathrm{O}$ as the obligatory possessor of the nominalized transitive verb. After reanalysis, the argument structure has both the nominative subject ( $<$ S of copula) and the absolutive verbal prefix ( $<$ obligatory possessive prefix); the matrix copula becomes an auxiliary (agreeing with A/S) and the nominalized verb is the new main verb. 
(25) The proposed etymological analysis of the Panare Desiderative

\begin{tabular}{|c|c|c|}
\hline $\begin{array}{l}{[[\text { PSSR-V-NZR }} \\
\text { witënëjté }\end{array}$ & $\begin{array}{l}\operatorname{POSTP}]_{\mathrm{PP}} \\
p i\end{array}$ & $\begin{array}{l}\text { S-COP } \\
\text { maj }\end{array}$ \\
\hline$\varnothing$-w-të-në-jté & pe & m-aj \\
\hline $1 S-S_{A}-g o-1+2 S-D E S I D . N Z R$ & ATTR & 2/3-COP.PAST \\
\hline
\end{tabular}

$\begin{array}{llll}\quad[\text { PSSR-V-NZR }] & \text { POSTP }]_{\mathrm{PP}} & \text { s:COP } & \mathrm{S} \\ \text { b. atyajté } & p e & k e ̈ j & k e ̈ n \\ \text { a-tya-jté } & \text { pe } & \text { këj } & \text { kën } \\ \text { 2O-hear-DESID.NZR } & \text { ATTR } & \text { 3.COP } & \text { 3.ANIM }\end{array}$

lit. 'He is (like) a wanter of the hearing of you'

So for both the Panare future tense and desiderative mood, the argument structure in the biclausal source construction becomes the nominative-absolutive alignment after reanalysis.

\subsection{The Mixed Nominalization Sources}

This third kind of source of the A/S pivot, mixed nominalization, is attested in both Panare (for the nonspecific aspect inflection) and Katxuyana (for the imperfective inflection). In each case, two distinct source constructions have merged, with one source construction providing the morphosyntax of the intransitive clauses and a different source construction providing the morphosyntax of transitive clauses. The reconstructions are secure (cf. Gildea 1998:184-186, 213-216), so we will only reprise briefly here. In both cases, intransitive verbs occur in the simple action nominalization, whereas for transitive verbs, they differ: in Panare, the transitive $V$ uses the agent nominalization, whereas in Katxuyana, the transitive $\mathrm{V}$ uses the action nominalization in a postpositional phrase. First we address the Panare case, beginning with the English calque given in (26).

(26) The source for the Panare Nonspecific Aspect: S/A pivot

a. $\mathrm{I}_{i}$ am [ $\mathrm{my}_{i}$ walking] > I walk/am walking/will walk.

b. $\mathrm{I}_{i}$ am $\left[\varnothing_{i}\right.$ the book's writer $]>$ I write/am writing/will write the book

The action nominalizer (which can occur on both transitive and intransitive verbs) is $-n\left(<{ }^{*}\right.$-rì), and the agent nominalizer (which can occur only on transitive verbs) is $-\tilde{n} e\left(<{ }^{*}\right.$-ne[mi]). When each occurs as the complement of a copula, the combination establishes an $\mathrm{A} / \mathrm{S}$ pivot (the copular subject $=$ $\mathrm{S} / \mathrm{A}$ ), with the result that the copular subject becomes the nominative of the 
reanalyzed clause. Because both nominalizations are obligatorily possessed (the action nominalization by the subordinate $S$ and the agent nominalization by the subordinate $\mathrm{O}$ ), the structure of the absolutive is retained as well. The examples in $(27 \mathrm{a}-\mathrm{b})$ show the presumed etymologies for modern nonspecific aspect clauses.

$$
[\text { PSSR-V-NZR }]_{\text {PRED }} \text { S.COP S }
$$
a. yutën
këj kën
y-w-të-n
këj kën
3S-INTR-go-NZR 3.COP 3.ANIM
lit. 'he is his $_{i}$ going' (> 'he goes / is going / will go')

$\begin{array}{llll}\text { [PSSR } & \text { V-NZR } & ]_{\text {PRED }} \text { S.COP } & \text { S } \\ \text { b. osowantënë } & \text { yaartkañe } & \text { kë' } & \text { i'yan } \\ \text { as-awantë-në } & \text { y-aarika-ñe } & \text { kë' } & \text { piyan } \\ \text { DETR-make.ill-INF } & \text { RP-remove-A.NZR } & 3 \text { 3.COP } & \text { shaman } \\ \text { lit. 'The shaman is illness' remover.' } & & \\ \text { (> 'The shaman removes / is removing/ will remove the illness') }\end{array}$

The Katxuyana imperfective pattern is illustrated with the English calques in (28):

(28) The sources for the Katxuyana Imperfective Aspect
a. $\mathrm{I}_{i}$ am
my $_{i}$ walking] $>$ I am walking/habitually walk.
b. $\mathrm{I}_{i}$ am $\left[\right.$ on $\left[\varnothing_{i}\right.$ the book's writing] $]>\mathrm{I}$ am writing/habitually write the book.

The intransitive imperfective allomorph is simply the action nominalizer - $r$, with no unique phonological changes to distinguish it. The transitive imperfective allomorph is the same action nominalization, but made of the object of a locative postposition: -ri hoko (< ${ }^{*}$-ri pôkô) which is then subject to idiosyncratic phonological reduction: ${ }^{21}$ initially to -rhoko, then to -roko and even to the extreme of -rko on the high frequency lexical item ka 'say'. Thus, Katxuyana collapses a predicate nominal construction and an adverbial predicate

21 Gildea (1998:198ff) reconstructs the postposition *poko 'on the surface of', and shows that a modern reflex is attested in many Cariban languages with the meaning 'occupied with'; Meira \& Franchetto (2005) offer good evidence of the need to distinguish between *o and *ô (mid back/central unrounded) in Proto-Cariban, and Gildea, Hoff \& Meira (2010) show that * pôkô is the more plausible reconstruction. 
construction into a single suppletive inflection in a nominative-absolutive imperfective construction. As already seen, the action nominalization in the postpositional phrase provides a ready S/A pivot, and as such, this combination of constructions provides precisely the necessary conditions for the creation of the nominative-absolutive alignment. The examples in (29) show the reconstructed sources for the two Katxuyana imperfective clauses.

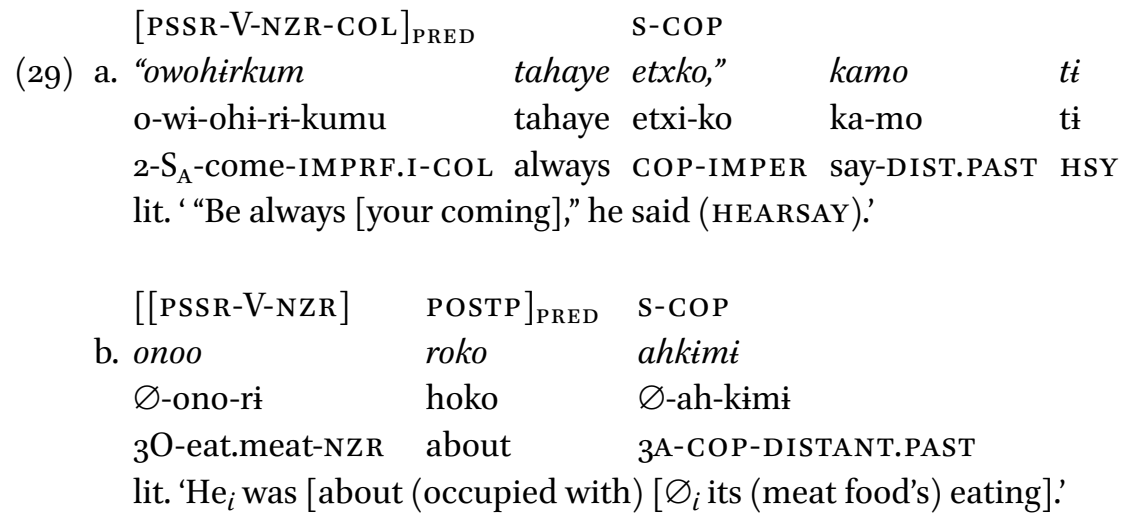

Here, for the first time we see a typologically unusual pathway for the creation of an innovative construction, in which speakers of two different languages have selected different subordinate clause structures and merged them into a single suppletive inflection/construction. Such a merging of two distinct source constructions has also given rise to a progressive attested in six modern Cariban languages, including Panare (reconstructed in Gildea 1998: 197-217). A relatively recent issue of Studies in Language was dedicated to the topic of multiple source constructions in syntactic change, and in the lead article, Van de Velde et al. (2013) suggest that the phenomenon is much more common than most realize, simply because we as a field have not focused much attention on it.

To summarize, all three types of biclausal sources presented in Section 5 are similar in that the morphological and syntactic properties of their source constructions lead to the creation of a nominative category (the S/A of the matrix clause in the source construction) and the absence of an explicit marked A in the subordinate clause structure, giving rise in a fairly mechanical way to the nominative-absolutive alignment we encounter in the various synchronic constructions. In the next section, we turn to the final type of source, which originally retained the marked $\mathrm{A}$, and in which the attested synchronic nominative-absolutive alignment is created by later replacement of the marked (ergative) A with an unmarked A. 


\section{Creating Nominative-Absolutive through Loss of Ergative Case-Marking}

There are two different construction types, both in the Jê family, in which the nominative-absolutive pattern is created through loss of the ergative casemarker, or perhaps more correctly, through replacement of the marked A from the source construction with an unmarked A. For each of these examples, there are also contexts in which the ergative-marked A is not lost, thereby creating a split, with one construction maintaining the ergative-absolutive alignment and another shifting to nominative-absolutive alignment.

In these constructions we find the combination of properties we expect to accompany innovative Tense-Aspect-Modality (TAM) in northern Jê: the main verb is in the nonfinite form (often followed by an auxiliary) and the absolutive argument, which has no case-marking, immediately precedes the main verb or is expressed as a bound pronoun/prefix on the verb. The innovative splits are only in case-marking of the A. In the Canela evaluative (30) and negative constructions (31), the past tense is identifiable by the fact that the $A$ bears ergative case (3od, 31a) and the $S$ is internal to the VP (3oc). The nonpast evaluative and negative construction has a different treatment of $\mathrm{A} / \mathrm{S}$ : in the intransitive nonpast, the S NP is external to the VP and the nonfinite verb bears an S prefix (3oe); in the nonpast transitive, the A lacks the ergative case-marker (3of, $31 \mathrm{~b}) .{ }^{22}$

(30) Canela evaluative modes: 'well' and 'a little'

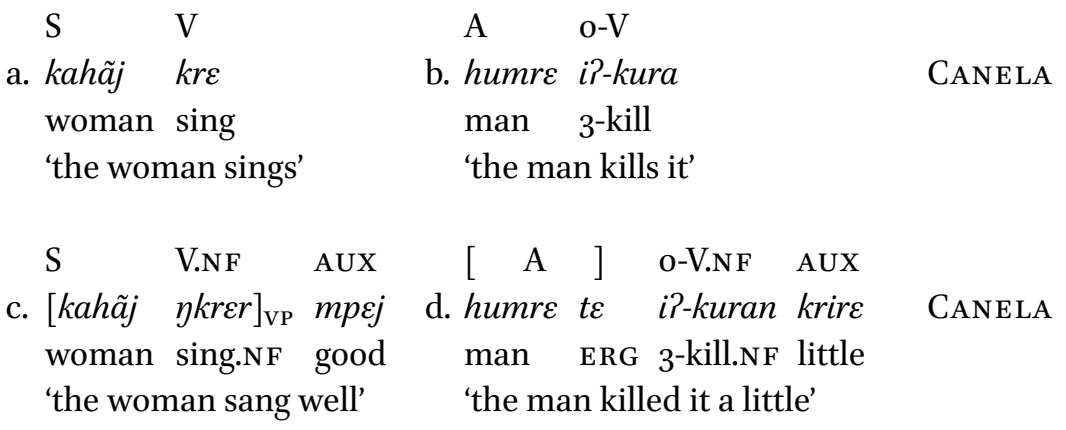

22 This argument structure difference actually led Popjes \& Popjes (1986: 180) to analyze the ergative case-marker $t \varepsilon$ (which only occurs with the "long form" of the verb) as the morphological marker of past tense; this unfortunate decision led them to consider intransitive clauses as lacking a means to indicate past tense. 

S $\quad \mathrm{s}-\mathrm{V}$
AUX
A
o-V.NF
AUX

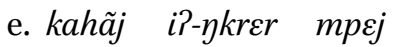
f. humre i?-kuran
krire
CANELA woman 3-sing.NF good man 3-kill.NF
little
'the woman sings well'
'the man kills it a little'

(31) Canela negative past (ergative-absolutive) and nonpast (nominativeabsolutive)
[A ERG]
$\left[\begin{array}{ll}\mathrm{O} & \mathrm{V} . \mathrm{NF}\end{array}\right]$ AUX
a. aikrajre te $n \tilde{\varepsilon} \quad h \tilde{\iota} \quad k r \tilde{\varepsilon} r \quad n a r \varepsilon$
CANELA
child ERG NEG meat eat.NF NEG
'The child didn't eat meat.' (Castro Alves 2004: 129)
A o-V.NF AUX
b. wa ha i?-pir nare
1 IRLS 3-grab.NF NEG
'I will not grab it'

CANELA

In the Kĩsêdjê future (32) and negative (33), all pronouns must occur in the ergative case (32b, 33b), whereas a full NP A is obligatorily unmarked (32a, 33a). For more detail and illustration of these synchronic patterns, cf. Castro Alves (2010), Gildea \& Castro Alves (2010) and the references therein.

(32) The Kĩsêdjê future with full NP and pronominal A
A
$\left[\begin{array}{ll}\mathrm{O} & \mathrm{V} . \mathrm{NF}\end{array}\right]$ AUX
a. ludu ra tep kuru mã
Ludo SM fish eat.NF FUT
KĨSÊDJÊ
'Ludo will eat fish' (Santos 1999: 232)
A-ERG $\quad\left[\begin{array}{ll}\mathrm{O} & \mathrm{V} . \mathrm{NF}\end{array}\right] \quad$ AUX
b. $i-r \varepsilon \quad h w i \tilde{s} \dot{t}$ ren mã
1SG-ERG fruit pick.NF FUT
'I will pick fruit' (Santos 1997:56)

(33) The Kĩsêdjê negative with full NP and pronominal A
A
[O
V] $\quad$ AUX

a. $\operatorname{rot} \iota$ ra mitfi piri

anaconda SM caiman kill.NF NEG

KĨSÊDJÊ

'The anaconda did not kill the caiman' (Santos 1997: 165) 

A-ERG $\quad[\mathrm{O}$
b. $i-r \varepsilon \quad$ hwĩggro
V]
AUX
1-ERG firewood RP-hang.NF NEG
'I didn't hang the firewood. (Santos 1997:56)
KĨSÊDJÊ

Given that Castro Alves (2010) has already presented the cognate ergative constructions for all four languages (pp. 463-466) and reconstructed the ergative constructions in Canela (pp. 466-473), our primary task in this section is to describe the situations in which the ergative case-marker is lost. We briefly reiterate Castro Alves' (2010) reconstruction of the source constructions that provide the grammatical morphology and source ergative-absolutive patterns (Section 6.1), then we argue that the topicalizing constructions in Kayapó, which create a (nominative, or unmarked) topic A alongside the prior ergative A, represent an intermediate stage that existed in these constructions for both Kĩsêdjê and Canela (Section 6.2); and finally (Section 6.3), we show how Kĩsêdjê and Canela have split each construction, selecting either the ergative or the nominative A according to person (Kĩsêdjê) or tense (Canela).

\subsection{The Nominalized Clause Is the S of an Intransitive Predicate}

Castro Alves (2010) reconstructs the negative and the evaluative modes as biclausal constructions in which an intransitive verb is the nucleus of the matrix clause and the nonfinite verb is its subject. To this, we add the reconstruction of the Kĩsêdjê future as a (nonverbal) predicate locative matrix clause with the nonfinite verb as the object of its postpositional (locative) phrase predicate. We begin with Castro Alves' reconstructions.

In the case of the intransitive matrix clause, the subordinate clause in its entirety serves as the $S$ of the matrix verb, as illustrated with the English calques

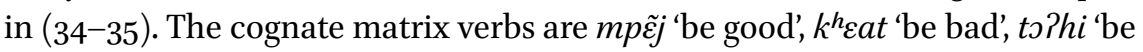
a lot', $\eta k r i=r \varepsilon$ 'be a little', $n a=r \varepsilon$ 'not exist' (< $n a=r \varepsilon$ 'finish/end up'), and ket/ kere 'not exist'.23

23 The negative auxiliary nare is found only in Canela, but we can find the cognate forms inore 'finish' in Mẽbêngôkre (Castro Alves 2010: 468-469), and nõ rõ NEG in Panará (Dourado 2001: 117-118); ket/kere is the negative form found in the other three languages: Kĩsêdjê ket before another predicating element (e.g., Santos 1997: 94) or the clitic =re '?' (Santos 1997: 96) and kere sentence-finally (e.g. Santos 1997: 95), Apinajé ket to negate nonverbal predicates and ket=nẽ to negate verbal predicates (Oliveria 2005: 249), and Mẽbêngôkre ket for verbal negation, but keti also attested in unknown contexts (Reis Silva 2001: 63 note 2). 
(34) a. There is no [salt $] \sim[($ the $)$ salt $]$ finished up/does not exist.

b. $[[$ My running $]$ finished up/does not exist $] \quad>$ I am not
running.

c. [[The meat's cooking by me] finished up/does not exist $]>\mathrm{I}$ am not

cooking the meat.

(35) a. [[The salt $]$ is good/bad/much/little $]$.

b. [[My running] is good/bad/much/little] > I am running well/badly/ a lot/a little.

c. [[The meat's cooking by me ] is good/bad/much/little $]$ > I am cooking the meat well/badly/a lot/a little.

This source reflects an S/Sentential pivot (Gildea's 1998, 2000 "pleonastic pivot"), in which the entire subordinate clause is (or is coreferential with) the sole participant in the main clause, i.e., the existence of the event expressed by the dependent clause is itself the sole semantic argument of the matrix clause. After reanalysis, the ergative-absolutive alignment pattern of the nonfinite clause surfaces intact into the new main clause, with an ergative-marked A NP or pronoun and the unmarked preverbal absolutive NP in alternation with an absolutive pronominal prefix on the verb. This is the source construction for the evaluative modes in Canela, plus negation in both Canela and Kĩsêdjê (and Mẽbêngôkre, as we will see in the next section). ${ }^{24}$

In the second source construction, which gave rise to the Kĩsêdjê future tense, an allative postposition becomes the future auxiliary. This source has not been reconstructed before, and it may be controversial - the outcome is certainly remarkable. We begin presentation of our hypothesis with the cognate set for the dative postposition $m \tilde{a}$, which is identical to the future auxiliary in Kĩsêdjê (36). Next, we present the simple verbless existential / predicate locative clause in Kĩsêdjê (37a), a construction with precise analogues in Canela (37b), Mẽbêngôkre (37c), and Panará (37d). In each case, the subject occurs first, followed by the (locative) predicate PP.

(36) Kĩsêdjê: $\quad$ mã 'Dative, benefactive, directionaL'

(Santos 1997: 97)

Canela: $\quad m \tilde{a}$ 'DAtive, Benefactive' (Castro Alves 2004: 8)

24 Castro Alves (2008:17; 2010:470-471) suggests that the recent past construction is derived historically by the loss of an earlier auxiliary. However, another hypothesis under exploration is that the recent past is a further development of a possessive perfect construction, which would have had no auxiliary in the source (cf. the cognate 'perfect' construction in Mẽbêngôkre, analyzed in great semantic detail - albeit in a very different framework - by Salanova 2007). 
Apinajé: $\quad$ mã 'DATIVE, Benefactive, Locative'

(Oliveira 2005: 141-142)

Mẽbêngôkre: $m \tilde{\imath}$ 'DATIVE, ALlative, PRospective'

(Reis Silva 2001: 43)

Panará mã 'DATIVE, BENEFACTIVE, ALLATIVE'

(Dourado 2001: 55)

S

$$
\left[[\text { Possr Possd }]_{\mathrm{NP}} \quad \mathrm{P}\right]_{\mathrm{PP} / \text { PRED }}
$$
a. aket
ra kosı kre
kãm
KĨSÊDJÊ
the.rest SM basket interior LOC

'The rest (is) in the basket' (Santos 1997: 140)
b. kwar pur $k^{h} \tilde{a} m$
manioc garden LOC
CANELA

'There is manioc in the garden.' (Castro Alves 2004: 124)

$\begin{array}{ccll}\text { c. } m r u & *(n \tilde{e})^{25} & \text { br } & \text { kam } \\ \text { game } & \text { NFUT } & \text { woods } & \text { in }\end{array}$

'The animal is in the woods.' (Salanova 2007: 110)
d. $k u \dot{t}$
рии уата̃
manioc garden LOC
'There is manioc in the garden' (Dourado 2001: 99)

MẼBÊNGÔKRE

To derive the source construction from this matrix clause, we simply replace the possessed lexical noun in the predicate PP with a nonfinite verb and its complements, giving us clauses like the English calques in (38b-c). In (39), we see a clause from Mẽbêngôkre that is virtually identical to the Kĩsêdjê future construction, presented by Salanova as a synchronic predicate locative construction, i.e., as exactly the analysis that we reconstruct for the antecedent of the Kĩsêdjê future.

(38) a. It (is) [in [the basket].

b. It (is) [to [my walking]] > 'I (ABS) will/am about to walk'

c. It (is) [to [the meat's cooking (by me)]] > I (ERG) will/am about to cook the meat'

25 We interpret this *() to mean that the $n \tilde{e}$, which indicates that the preceding element is in focus position, is obligatory (ungrammatical if optional), cf. Salanova's prose before the example: "But to predicate of a locatum focalization seems to be required." 
$\begin{array}{lllll}\text { (39) } \text { arrm } & \text { kute } & t \varepsilon p & k r e ̃ n & m \tilde{\imath} \\ \text { already } & \text { 3ERG } & \text { fish } & \text { eat NF } & \text { to }\end{array}$

MẼBÊNGÔKRE

'He's already about to eat fish.' (Salanova 2007:56)

(lit. 'Already (it is) to the eating of fish by him')

In this particular source construction, neither the existential subject nor a copula occurs explicitly, leaving only the ergative-absolutive argument structure of the erstwhile nominalization to express the core arguments.

Having reconstructed all of these split systems to constructions that represent the $\mathrm{A}$ argument as an oblique and the $\mathrm{O} / \mathrm{S}$ arguments as possessors of the nonfinite verb form, we turn next to the elaboration of these constructions that introduced the option of an unmarked A.

\subsection{Subject Pronoun Doubles}

In the grammar of all the Northern Jê languages, we find descriptions of a focus (sometimes called "cleft") construction, in which a focused noun or (nominative) pronoun occurs in first position, followed by a normal clause of whatever type, often with a resumptive pronoun that indicates the grammatical role of the preceding topicalized NP. We also find descriptions of a "subject doubling" rule, in which a noncanonical (i.e., non-nominative) subject may be doubled via a nominative pronoun, which is often described as though it were identical to the focus pronoun, but which may be distinguished in several ways from a pronoun in the focus position. First, the subject copy pronouns do not appear to give additional emphasis or "focus" to the clause, but rather they simply mark the TOPIC with some frequency (in some cases, obligatorily) before certain tense-aspect particles, e.g. $h a$ 'irrealis' in Canela (Castro Alves 2004: 95).

$\begin{array}{clll}\text { (40) } & \begin{array}{l}\text { TOP } \\ \text { ke ha hümre ropti j-ahe }\end{array} & \text { CANELA } \\ 3 & \text { IRLS man jaguar RP-hunt } & \\ \text { 'The man will hunt a jaguar.' (Castro Alves 2004: 95) }\end{array}$

TOP A

b. wa ha i-mã h-ũpa

CANELA

1 IRLS 1-DAT 3-fear'

'I will fear him.' (Castro Alves 2004: 100)

TOP S

c. ke ha hũmre i?-ykrer nare

CANELA

3 IRLS man 3-sing.NF NEG

'The man will not sing.' (Castro Alves 2004: 111) 


\section{TOP A \\ d. $w a \quad i-t \varepsilon \quad k u$-mã ropti j-akre \\ 1 1-ERG 3-DAT jaguar PR-show \\ 'I showed him the jaguar.' (Castro Alves 2004: 118)}

CANELA

Santos (1997: 58-60) also discusses the "construction with topicalized pronouns", and while he does not specify anything about the grammatical role of these nominative forms that immediately precede the core of the clause, his examples are consistent with the claim that the topicalized pronoun is always coreferential with the subject (cf. 41a-b). ${ }^{26} \mathrm{~A}$ similar set of examples is available for Mẽbêngôkre (41c-d) - about these topic pronouns, Salanova (2007: 34-35) asserts:

The unusual characteristic of nominative pronouns is that, in main clauses, they can duplicate a subject that is already expressed lower in the clause by an ergative, dative or absolutive pronominal form. These pleonastic nominative pronouns, unavailable in embedded clauses, seem not to indicate any emphasis ... We take the ability to be "duplicated" by a nominative pronoun in the position between tense and aspectual particles as the primary diagnostic for subjecthood in Mẽbêngôkre main clauses. (Salanova 2007: 34-35)

(41) Nominative topic pronouns in Kĩsêdjê (a-b) and Mẽbêngôkre (c-d)

\section{KĨSÊDJÊ}

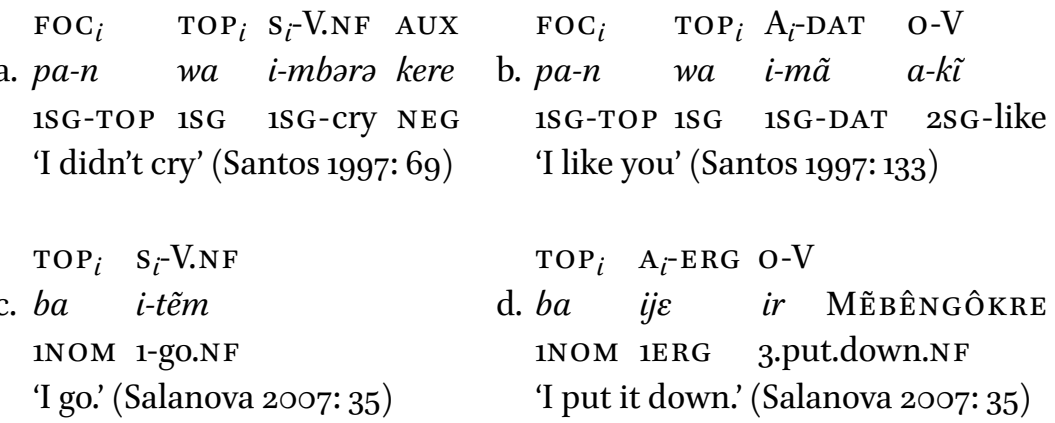

While sometimes appearing identical (the pronominal forms are the same), a focused element differs in that (i) it is pragmatically marked, e.g. for contrast, (ii) it may be either a full NP (42a-b) or a pronoun $(42 \mathrm{c}-\mathrm{d}, \mathrm{f}-\mathrm{g})$, (iii) it is not limited to the subject role (42b, e, g), and (iv) in at least Mẽbêngôkre, it occurs

26 Note that (41a-b) also contain initial focused pronouns (marked with $-n$ 'TOP'), which we discuss in the next paragraph. 
in a different position vis-à-vis the tense and aspect particles, e.g. preceding $n \tilde{e}$ 'NONFUTURE' or $d z a$ 'IRREALIS/FUTURE' (Salanova 2007: 34; 110, note 24; 131, note 50); in Kĩsêdjê, it is consistently marked with the suffix/particle $-n /$ $n a$ 'FOCUS' (42e-f). While it is not obligatory, a focused element may be coreferential with the nominative pronoun (42a, $\mathrm{c}-\mathrm{d}, \mathrm{f})$, the ergative A pronoun (42d, $\mathrm{f}$ ), or the absolutive $\mathrm{S}$ prefix (42f). Example (42f) is remarkable for having four different forms that refer to the same subject participant: from the left, the first element is the FOCUS form $p a-n$ 'ISG-TOP'; the second is the nominative TOPIC form $w a$ ' $1 S G$ '; the third is the ergative form $i-r \varepsilon$ 'ISG-ERG', which is allowed uniquely in future, progressive, and negation when a postpositional goal phrase occurs between this S pronoun and the verb (cf. Gildea \& Castro Alves 2010: 188-189 for the argument that this is evidence for reanalysis of the Kĩsêdjê future and negative); and finally, the only one of these that is obligatory, the $S$ prefix on the nonfinite main verb $i$-tz̃m ' $1 S G$-go.NF'. Such sequences of coreferential pronouns are found in elicitation in several Northern Jê languages, but in Castro Alves' Canela text database, no more than two such coreferential pronouns are found in a single clause. It is possible that such extreme redundancy is an artifact of the elicitation situation.

(42) NPs in focus position in Canela (a,f), Mẽbêngôkre (b-d), Kĩsêdjê (e) $\begin{array}{lllll}\mathrm{FOC}_{i} & \mathrm{~A}_{i} & \text { TAM } & \mathrm{O} & \mathrm{V}\end{array}$

a. intuw ke ha ropkror pupu

CANELA youth 3 IRLS jaguar see 'The youth, he will see a jaguar.' (Castro Alves 2004: 95)

$\mathrm{FOC}_{i}$ TAM $\mathrm{O}_{i}-\mathrm{V}$

b. $m r m \quad n \tilde{e} \quad k u-b \tilde{\imath}$ MẼBÊNGÔKRE

animal NFUT 3 ACC-kill.sG.v

'He killed an animal (focus).' (Salanova 2007: 34)

$\mathrm{FOC}_{i}$ TAM TOP $_{i} \quad \mathrm{~s}_{i}$-V.NF

c. $b a \quad n \tilde{e} \quad b a \quad i$-tẽm

MẼBÊNGÔKRE

1NOM NFUT 1NOM 1-go.NF

'I go.' (Salanova 2007: 35)

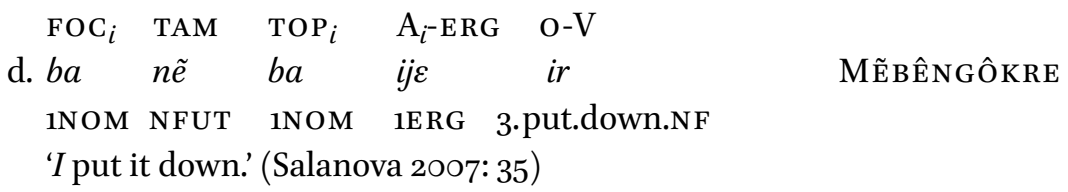




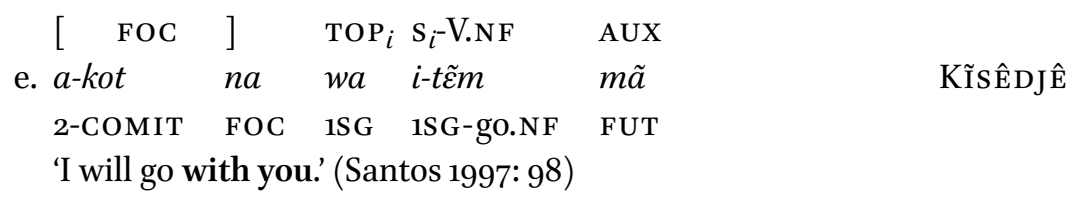

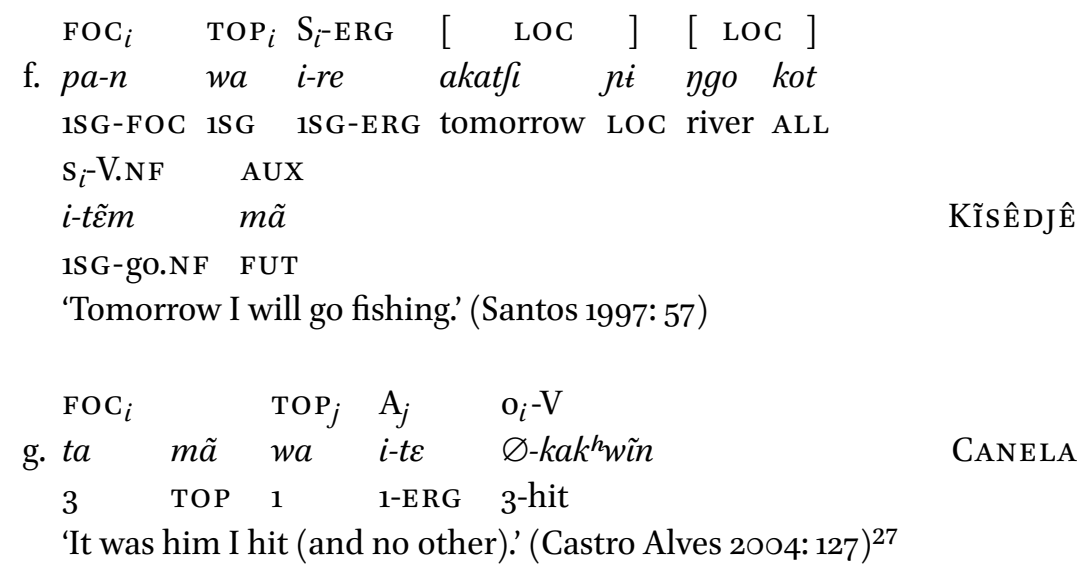

We are now able to return to the innovative ergative constructions that we reconstructed in Section 6.1 in order to illustrate the relevance of subject doubling, whether via the TOPIC or the FOcus slots at the beginning of the clause: it creates a context in which the subject is frequently expressed twice (or three times), once closer to the verb via the ergative argument inherited from the nominalized clause in the source, but also closer to the beginning of the utterance via forms that do not bear ergative case: either a focus NP/pronoun, the nominative subject doubling TOPIC pronoun, or both. In (43), we show examples from Mẽbêngôkre: (43a) is the simple case, the source of the negative with only the argument structure of the embedded nominalization (i.e., with the TOPIC and Focus slots unfilled); (43b) is the same type of clause, except with the TOPIC slot filled by a nominative pronoun. The reverse order of marking is also attested, with an unmarked initial A NP, presumably in FOcUs

27 Example (42g) was produced in answer to the question 'Who did you beat?', making it clear that the pronoun $t a$ ' 3 ' is a focused element. This focused pronoun is followed by the particle $m \tilde{a}$, which Castro Alves (2004) glosses as 'TOPIC'. Here we do not change the original gloss, although we do recognize that additional research into Canela discourse will be necessary to resolve the conditions in which $m \tilde{a}$ marks focused elements (for example, one hypothesis might be that a focused element followed by $m \tilde{a}$ signals a new topic in the subsequent discourse). 
position (given that TOPIC position is only filled by pronouns), followed by a coreferential ergative pronoun $(43 \mathrm{c}) .^{28}$

\begin{tabular}{|c|c|c|c|c|}
\hline TOP & [[ Овц ] & & POSSR-V.NF $]_{S}$ & $\mathrm{~V}_{\text {INTR }}$ \\
\hline 3) a. & $\begin{array}{l}\text { kaitire } \\
\text { Kaitire }\end{array}$ & $\begin{array}{l}t \varepsilon \\
\text { ERG }\end{array}$ & $\begin{array}{l}\varnothing \text {-mari } \\
\text { 3-know.NF }\end{array}$ & $\begin{array}{l}\text { ket } \\
\text { NEG }\end{array}$ \\
\hline
\end{tabular}

'Kaitire doesn't know (it).' (Reis Silva 2001: 48)

(lit. 'The knowing of it by Kaitire does not exist')

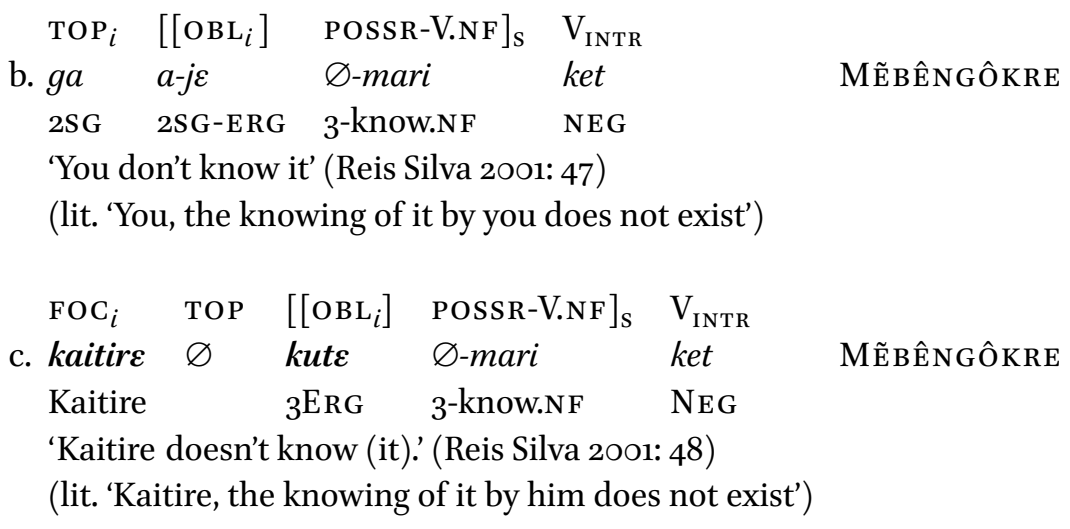

Similar examples are readily available for Mẽbêngôkre cognates to the Canela evaluative moods (44a) and to the Kĩsêdjê future (44b). In these two examples, we see the reconstructed ergative-absolutive alignment inside the nominalized clause that is the $S$ of the verb kumsj 'be many' (44a) and inside the predicate PP (44b); alongside the ergative A, in both cases we see an unmarked A double, the nominative TOPIC pronoun in (44a) and the unmarked FoCUs NP in $(44 b)$.

\author{
$\operatorname{TOP}_{i} \quad\left[\mathrm{OBL}_{i} \quad\left[\mathrm{PSSR}^{\mathrm{V}} \cdot \mathrm{NF}\right]\right]_{\mathrm{S}} \quad \mathrm{V}$ \\ $\begin{array}{lllll}\text { (44) a. } b a & i j \varepsilon & \varnothing \text {-krẽn } & \text { kumej } & \text { MẼBÊNGÔKRE } \\ \text { ISG } & \text { IERG } & \text { 3-eat.NF } & \text { be many } & \end{array}$ \\ 'I eat (something) a lot.' (Castro Alves field notes) \\ (lit. I, the eating of it by me is a lot.')
}

28 In response to a query by an anonymous reviewer, there are no published intonational data for Mẽbêngôkre - our analysis does predict a strong likelihood of distinctive intonation. 


\begin{tabular}{|c|c|c|c|c|}
\hline $\mathrm{FOC}_{i}$ & {$\left[\left[\mathrm{OBL}_{i}\right]\right.$} & Possr & V.NF $]_{\mathrm{NP}}$ & $\mathrm{P}]_{\mathrm{PP}}$ \\
\hline b. kubẽ & kute & $t \varepsilon p$ & krẽn & MẼBÊNGÔKRE \\
\hline non.Indian & $3 \mathrm{ERG}$ & fish & eat.NF & Prosp \\
\hline
\end{tabular}

We have now identified a commonplace construction in Mẽbêngôkre, Canela and Kĩsêdjê, that adds an unmarked nominative pronoun (in TOPIC position) or an unmarked A noun or pronoun (in FOcus position) to any clause that has non-nominative A or S. Crucially, these forms are attested in the source constructions that become the innovative evaluative moods and the negative construction in Canela and the negative and future in Kĩsêdjê. The stage is now set for the final step, whereby the selective loss of the ergative A in some contexts creates the attested split alignment patterns in Canela and Kĩsêdjê.

\subsection{Selective Loss of the Oblique A in Canela and Kĩsêdjê}

In the grammars of the northern Jê languages, it is commonplace to see examples with both a pronoun and an NP - or two different pronouns - jointly referring to the $\mathrm{A} / \mathrm{S}$ of a clause (Section 6.2), and it is not uncommon to see examples with three different pronominal forms indexing A (cf. 42c-d, f). Clearly this is a situation ripe for reinterpretation and simplification. While the unmarked topic (pro)noun can always co-occur with simple ergative-absolutive clauses in both Canela and Kĩsêdjê, whenever the topic pronoun occurs but the ergative pronoun does not, the result is a nominative-absolutive clause. In this section, we argue that the synchronic splits that have been described in Canela and Kĩsêdjê come from conservative ergative-absolutive constructions - in the past tenses in Canela and with pronominal A arguments in Kĩsêdjê - that are now in opposition with innovative nominative-absolutive constructions, which were created by suppression of the ergative A and retention of the doubled A TOPIC pronoun or FOCUS NP.

Considering first the tense-based split in Canela, the nonpast constructions are derived from the topic doubling construction via two changes. First, the topic pronoun becomes obligatory in the slot preceding second-position TAM particles. In the intransitive (45a), the subject doubling TOPIC pronoun becomes the obligatory nominative $\mathrm{S}$ pronoun, alongside the obligatory $\mathrm{S}$ prefix inherited from the absolutive possessor prefix on the nonfinite verb. In the transitive (45b), the subject doubling TOPIC pronoun becomes the nominative $\mathrm{A}$, which precedes the absolutive $\mathrm{O}$ (whether $\mathrm{NP}$ or prefix) inherited from the possessor of the nonfinite verb. Second, the marked ergative A form is lost 
(its former position is represented via the $\varnothing$ in $45 \mathrm{~b}$ ), leaving behind only the nominative A.

(45) Canela nonpast:Topic > Nominative A becomes obligatory, ergative A is lost $\mathrm{S} \quad[\mathrm{s}-\mathrm{V} . \mathrm{NF}] \quad \mathrm{V}_{\text {INTR }}$

a. wa ha i-wrik nare

CANELA

1 IRLS 1-descend.NF NEG

'I will not descend'

$\begin{array}{crrll}\text { A } & & & \text { [o-V.NF }] & \text { AUX } \\ \text { b. } w a & \text { ha } & \varnothing & \text { i?-pir } & \text { nare } \\ 1 & \text { IRLS } & \text { 3-grab.NF } & \text { NEG } \\ \text { 'I will not grab it' } & & \end{array}$

CAnela

Alongside these changes that create the nominative-absolutive pattern in the nonpast constructions, the past tense clauses remain conservative. In the past tense intransitive clause (46a), the TOPIC/FOCUs pronoun optionally cooccurs alongside the absolutive $S$ (46a), which now leads to ambiguity in interpreting the tense of the clause. In the past tense transitive clause, the inherited pattern is also still allowed, in which a TOPIC/FOcus pronoun optionally cooccurs alongside the ergative A (46b). However, there is also an innovative pattern, in which the unmarked position for the ergative A NP is at the beginning of the utterance, in the position etymologically reserved for the nominative pronoun (46c).

(46) Canela past: Oblique > Ergative A (doubling w/ Topic pronoun is allowed)
(тор) $\mathrm{s}-\mathrm{V}$
AUX
a. $k a$
$a-j-3 ? k u k^{h} r \tilde{\varepsilon} n$
nare
CAnela
2
2-RP-run.competing.NF NEG
'You didn't / don't run.'

(тоP) $\operatorname{erg} \quad\left[\begin{array}{ll}\mathrm{O} & \text { V.NF }\end{array}\right.$ AUX

b. $(k a) \quad a-t \varepsilon$ hi $k^{h} r \tilde{\varepsilon} r$ nare

Canela

2 2-ERG meat eat.NF NEG

'You didn't eat meat.' (Castro Alves 2008: 17)

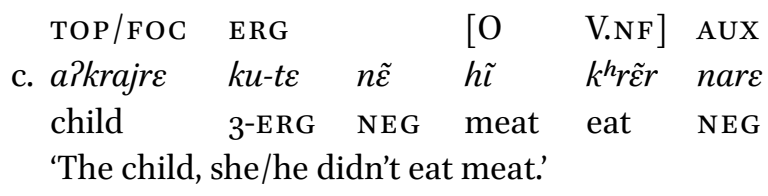

CANELA 
The simplification in Kĩsêdjê is not along the lines of tense-aspect, but rather along the lines of person: topic doubling (and even tripling) is attested with negative and future intransitive clauses $(47 \mathrm{a}-\mathrm{c})$, but it is not attested in transitive clauses (48-49). In transitive clauses in the negative (48a) and the future (49b), the innovative nominative-absolutive pattern is created by (i) obligatorily placing a full NP A referent in focus position, and (ii) dropping the third person ergative pronoun that once co-occurred (cf. the examples in Section 6.2) with that focused element. The particle $r a$ 'SUBJECT MARKER' often follows both A and S NPs in Santos' (1997) examples, but it is not obligatory (cf. p. 82, where in otherwise identical sentences the $A$ is unmarked, marked with $r a$, and marked with $-n$ 'topic'). Moreover, it is not entirely restricted to subjects (cf. the discussion on pp. 129-130, which includes examples of O marked with $r a)$. As such, despite the presence of $r a$ in most of these examples, we do not posit the innovation of a new nominative case-marker as a part of the creation of the nominative-absolutive pattern.

(47) The Kĩsêdjê topic doubling pronouns (Santos 1997: 119-120)
a. $i$-ygere $\quad m \tilde{a}$
ISG-dance.NF FUT
'I will dance'
b. wa i-ngere mã
ISG 1 SG-dance.NF FUT
'I (who) will dance'
c. $p a-n \quad w a$ i-ngere mã
1SG-TOP 1SG 1SG-dance.NF FUT
'I (who) will dance'

(48) The innovative nominative-absolutive: when A is an NP, use only TоPIC/ Focus position

$\begin{array}{lllllll}\text { FOC } & & { }^{*} \text { A-ERG } & {[\mathrm{O}} & \text { V.NF }] & \text { AUX } & \\ \text { a. } r s t f i & r a & \varnothing & \text { mitfi } & \text { piri } & \text { kere } & \text { KĨSÊDJÊ } \\ \text { anaconda } & \text { SM } & & \text { caiman } & \text { kill.NF } & \text { NEG } & \end{array}$

'The anaconda did not kill the caiman' (Santos 1997: 165)

(originally: 'The anaconda, (it) did not kill the caiman')
FOC
*A-ERG
O V.NF
AUX
b. ludu ra $\varnothing$
tep kuru mã
fish eat.NF FUT
KĨSÊDJÊ
'Ludo will eat fish' (Santos 1999: 232) (originally: 'Ludo, (he) will eat fish')

Alongside the construction that lost the ergative A NP (and even the ergative resumptive pronoun), Kĩsêdjê has retained the ergative marking only when 
the $\mathrm{A}$ is a pronoun (49a-b). From the related languages, we know that coreferential topic and/or focus pronouns would have been able to co-occur with the ergative pronoun and we see no reason that this should not still be possible in modern Kĩsêdjê; with that said, we encountered no examples of topic or focus pronouns doubling the ergative A pronouns in Santos' $(1997,1999)$ examples. If topic or focus pronouns cannot co-occur with a coreferential ergative A pronoun in modern Kĩsêdjê, this would be one more example of a quirky pattern that is limited to the innovative negative and future constructions.

(49) The conservative Ergative-Absolutive: when A is a pronoun, retain the ergative

\begin{tabular}{cllll} 
TOP/FOC & A-ERG & O-V & AUX \\
a. $\varnothing$ & ko-re & i-kaken & kere & KĨSÊDJÊ \\
& 3-ERG & 1SG-scratch.NF & NEG & \\
\multicolumn{4}{c}{ 'He didn't scratch me' (Santos 1997: 132) }
\end{tabular}

\begin{tabular}{|c|c|c|c|c|c|}
\hline \multirow{3}{*}{$\begin{array}{l}\text { TOP/FOC } \\
\text { b. } \varnothing\end{array}$} & A-ERG & $\mathrm{O}$ & V.NF & AUX & \multirow{3}{*}{ KĨSÊDJÊE } \\
\hline & & hwĩst & & $m \tilde{a}$ & \\
\hline & 1SG-ERG & fruit & pick.NF & FUT & \\
\hline
\end{tabular}

With this, we have now completed all of the actual reconstructions. We turn now to our conclusion, in which we summarize the reconstructions and show how they address the questions posed in the introduction.

\section{Discussion: Reconstruction, Diachrony and Universals}

We begin our discussion by returning to the outstanding questions from the introduction, after which we summarize our reconstructions and show how they address these questions.

First, it is typologically rare for argument marking to be nominativeaccusative while verbal indexation is ergative-absolutive - how did this rare pattern develop in these languages? Second, considering the typological tradition of identifying a construction (and even an entire language) as ergative given just one robust ergative alignment pattern, the absolutive prefixation is sufficient to identify these constructions as belonging to the "ergative" type. However, each construction participates in an alignment split that is conditioned by tense, aspect, mood, and polarity values that are expected to condition the non-ergative side of such splits. Our reconstructions actually explain both of these unexpected outcomes as resulting from normal 
grammatical changes that departed from a typologically unusual source construction.

We begin by observing that most of these reconstructions are quite robust, and require no unusual or surprising mechanisms of syntactic change. All of the reconstructions in Section 5 are simply additional examples of well-trodden pathways by which speakers recruit innovative tense-aspect-mood distinctions from existing biclausal constructions. So far as we know, innovations like these are attested in every language that has been recorded for longer than a few hundred years, creating a sufficiently robust body of examples to allow typologies of the sources (e.g., Bybee et al. 1994; Heine \& Kuteva 2002). The reconstructions of the innovative ergative-absolutive patterns in Section 6 are similarly robust, reflecting the same kinds of reanalyses seen elsewhere in the literature.

What is unusual about these language families is that the biclausal source constructions that feed into these innovative tense-aspect-mood-negation constructions have very limited resources for expressing nonfinite clauses - in these cases, all of the constructions in question are based on nominalizations that are inalienably possessed by their notional absolutive argument. In her detailed survey of alignment patterns in nominalizations, Koptjevskaja-Tamm (1993: 223-228) finds that it is unremarkable (25 of the 70 languages in her sample) to have a nominalization that is possessed by its absolutive, with the A expressed distinctly, usually as an oblique. However, 22 of these 25 languages have multiple other subordination strategies (they are "complement balancing", in her terms); the three that have more limited subordination strategies include one Cariban language, Hixkaryana, and two NE Caucasian languages, Abkhaz and Georgian. While Hixkaryana is typical of the Cariban family in basing almost all subordination on such nominalizations, both Abkhaz and Georgian have a range of non-ergative subordination strategies available for both adverbial and relative clauses (Hewitt 1987). In sum, all the other languages attested as having ergatively organized nominalizations also have other (non-ergative) subordinating structures available for the creation of innovative tense-aspect-mood constructions; in contrast, such nominalizations are the dominant strategy in the Cariban and Jê language families, which have almost no alternative structures available. ${ }^{29}$

Because the source constructions all contain this possession $>$ absolutive alignment pattern, every innovative tense, aspect, mood, or negation

29 Clearly, it would be desirable to conduct additional typological research to further study this claim: how many of the languages that have ergatively-organized nominalizations use them frequently in the sort of constructions that develop into innovative TAM? If our explanation for the relative rareness of the nominative-absolutive alignment pattern is correct, then this number should be quite low. 
construction whose source contains one of these possessed nominalizations will, perforce, end up as a construction with absolutive verbal indexation. So in fact, there is no need to invoke any unusual functional factor to explain the creation (and hence the synchronic existence) of the absolutive indexation in these innovative tense-aspects. The absolutive indexation pattern was not in competition with other patterns, and so was not selected for some particular reason that we might capture in a typology: it is simply the basic building block of dependent clauses.

Although we no longer need to provide a functional explanation for the presence of absolutive indexation, we do need to explain the existence of the nominative patterns, as the same nonfinite source construction contains an oblique notional A, which, in both families (and in some cases, in the same languages), does surface as an ergative A in other innovative main clause constructions. Once again, the reconstructions are robust and follow well-attested patterns:

- Transitive phasal verbs predicate the initiation or termination of activity by an agent (Section 5.1), thereby creating the A/S pivot in the innovative completive construction

- Source constructions that locate an agent in the midst of an activity (Section 5.2.1) create an $\mathrm{A} / \mathrm{S}$ pivot that becomes a nominative-accusative progressive construction (Heine 1994; Bybee et al. 1994, chapter 5; Gildea 1998: 36-37), which then evolves semantically to become a more general imperfective

- Source constructions that predicate the desire of or an obligation imposed upon an agent similarly create an A/S pivot with a subordinate construction (Section 5.2.2), thereby leading to a nominative pattern associated with agent-oriented modalities (which then can easily evolve into future tense)

Each of these source constructions has a matrix clause that selects as its subject the notional $\mathrm{A} / \mathrm{S}$ of the nonfinite clause, which leads to (i) nominative grammatical patterns (case-marking, order and auxiliary agreement) in the resultant construction and (ii) the suppression of the optional oblique $A$ in the nonfinite clause, thereby removing the source for an ergative A. Not coincidentally, the semantics of these source constructions are similarly agent-oriented, and thus lead to precisely the (agent-oriented) tenses, aspects, and moods that we expect to see associated with the non-ergative side of TAM-based splits. In other words, the innovation of these nominative patterns is motivated, and in the process, has conveniently removed a prior ergative case-marker from the source construction. If it were not for the retention of the conservative absolutive indexation pattern, these agent-oriented tense-aspect-moods would now fall where they belong typologically, on the non-ergative side of a tense-aspectmood based split ergative system. 
Hence, our reconstructions from Section 4 explain the presence of absolutive indexation and our reconstructions from Section 5 explain how innovative nominative case-marking (and other patterns) were added to that older absolutive pattern, thereby accounting for the counter-universal combination of alignment patterns. It is similarly clear how the innovative ergative-absolutive patterns in Section 6 were created, but we have no similarly robust explanation for the two different patterns of selective loss of ergative marking in Canela and Kĩsêdjê. On the one hand, it is well attested that case-markers can simply erode or stop being used, and many linguists have identified languages that appear to have lost an ergative case-marker within a given construction (e.g., Givón 1980, Estival \& Myhill 1988, Dixon 1994, Harris \& Campbell 1995, etc.). On the other hand, we are aware of only one other carefully documented case where the loss of the ergative case-marker is not complete, but is rather selective, leading to a specific pattern of split ergativity.

This change, showcased in a recent study by Guillaume (2015), documents the creation of a counter-universal case-marking split in Tacana (Takanan, Bolivia), where the ergative is obligatorily retained only for ISG and 2SG A pronouns, is optionally retained for all third persons, and is completely lost for 1PL and 2PL pronouns. While there are multiple surveys in the literature about how ergative patterns are created diachronically (e.g., Anderson 1977; Dixon 1994; Harris \& Campbell 1995; Gildea 2004), there is not a similarly rich research tradition about the processes by which alignment patterns in general - and ergative case-marking in particular - are lost. Combined with Guillaume's (2015) findings, our findings in this article suggest that attrition might create interesting transitional patterns of splits, either in the universal direction, as in Canela, or in the counter-universal direction, as in Kĩsêdjê and Tacana. This might be a fruitful direction to explore in future studies in diachronic alignment typology.

At this point, we can only speculate about the motives of those speakers who made the changes inherited by modern Canela and Kĩsêdjê speech communities. In Canela, it appears that they chose to always use the topic/focus position for the nominative argument uniquely in nonpast situations, so A/S topic/focus constructions were overused in nonpast situations and eventually evolved into indexical markers of nonpast tense. In contrast, agent focus/ topic must have been rare in past situations, leading to a situation in which the absence of an A/S noun or pronoun in topic/focus position (and, for transitive clauses, retention of the ergative case-marker) came to index past tense situations. Similarly, the existing case-marking patterns in Kĩsêdjê associate ergative marking uniquely with pronouns, which means with continuing topics, whereas a free A NP must have occurred frequently in focus position, presumably originally with a resumptive (ergative) pronoun. Over time, speakers 
appear to have stopped using an ergative-marked A NP inside the clause, expressing the A NP only in focus position; when they also stopped using the resumptive ergative pronoun, the result would be the attested split alignment pattern. It would be most interesting to enquire if similar statistical asymmetries in focus constructions are attested in texts from closely related languages (such as Mẽbêngôkre and Apinajé) that have not made them obligatory grammar as they are in Kĩsêdjê. Alternatively, similar information structure asymmetries might be observable in completely unrelated languages for which we have larger, more readily searchable corpora.

However, these remain questions for future research - here we can reconstruct the historical changes that must have taken place, but unlike the reconstructions from Section 5, these reconstructions do not help us to explain the resultant patterns.

\section{Abbreviations}

1

2

3

$1+2$

ABIL

ACC

ADV

AGT

ALL

ANIM

ASP

ATTR

AUX

CIRC

$\mathrm{CNJ}$

COL

COMIT

COMPL

CONCL

COP

DAT

DEF

DESID
First person

Second person

Third person

First person dual inclusive

Abilitative

Accusative

Adverbial

Agent

Allative

Animate

Aspect

Attributive

Auxiliary

Circumstantial

Conjunction

Collective

Commitative

Completive

Conclusive

Copula

Dative

Definite

Desiderative

\begin{tabular}{|c|c|}
\hline DETR & Detransitive \\
\hline DIR & Directional \\
\hline DIST & Distal Deixis \\
\hline DUR & Durative \\
\hline EMPH & Emphasis \\
\hline ERG & Ergative \\
\hline ESS & Essive \\
\hline FACT & Factitive \\
\hline FOC & Focus \\
\hline FUT & Future \\
\hline GEN & Genitive \\
\hline HSY & Hearsay \\
\hline I & Intransitive \\
\hline IMPER & Imperative \\
\hline IMPRF & Imperfective \\
\hline INF & Infinitive \\
\hline INSTR & Instrumental \\
\hline INTR & Intransitive \\
\hline INVIS & Invisible \\
\hline IRLS & Irrealis \\
\hline LOC & Locative \\
\hline NEG & Negative \\
\hline NF & Nonfinite \\
\hline
\end{tabular}




$\begin{array}{llll}\text { NFUT } & \text { Nonfuture } & \text { RLS } & \text { Realis } \\ \text { NOM } & \text { Nominative } & \text { RP } & \text { Relational Prefix } \\ \text { NZR } & \text { Nominalizer } & \text { S }_{\text {A }} & \text { S }_{\text {A verb class prefix }} \\ \text { OBL } & \text { Oblique } & \text { SBRD } & \text { Subordinate } \\ \text { PAST } & \text { Past } & \text { SG } & \text { Singular } \\ \text { PL } & \text { Plural } & \text { SM } & \text { Subject Marker } \\ \text { POSSD } & \text { Possessed } & \text { SS } & \text { Same Subject } \\ \text { POSTP } & \text { Postposition } & \text { T } & \text { Transitive } \\ \text { PR } & \text { Relational Prefix } & \text { TAM } & \text { Tense-Aspect-Modality } \\ \text { PROSP } & \text { Prospective } & \text { TEMP } & \text { Temporary } \\ \text { PV } & \text { Preverbal Particle } & \text { TOP } & \text { Topic } \\ \text { REL } & \text { Relativizer } & \text { TRN } & \text { Transitive }\end{array}$

\section{References}

Aikhenvald, Alexandra, R. M. W. Dixon, \& Masayuki Onishi, eds. 2001. Non-Canonical Marking of Subjects and Objects. Amsterdam: John Benjamins.

Anderson, Stephen R. 1977. On Mechanisms by which Languages Become Ergative. Mechanisms of Syntactic Change, ed. by Charles N. Li, 317-363. Austin: University of Texas Press.

Barðdal, Jóhanna \& Spike Gildea. 2015. Diachronic Construction Grammar: Epistemological Context, Basic Assumptions and Historical Implications. Diachronic Construction Grammar, ed. by Jóhanna Barðdal, Elena Smirnova, Lotte Sommerer \& Spike Gildea, 1-5o. Amsterdam: John Benjamins.

Blevins, Juliette 2004. Evolutionary Phonology: The Emergence of Sound Patterns. Cambridge: Cambridge University Press.

Bybee, Joan, Revere Perkins \& William Pagliuca. 1994. The Evolution of Grammar: Tense, Aspect and Modality in the Languages of the World. Chicago: University of Chicago Press.

Camargo, Nayara S. 2015. Tapayuna (Jê): aspectos morfossintáticos, históricos e sociolinguísticos. Ph.D. dissertation, Universidade Estadual de Campinas.

Castro Alves, Flávia de. 2004. O Timbira falado pelos Canela Apãniekrá: uma contribuição aos estudos da morfossintaxe de uma língua Jê. Ph.D. dissertation, Universidade Estadual de Campinas.

Castro Alves, Flávia de. 2008. O papel das nominalizações na evolução do alinhamento ergativo nas línguas Jê: Dimensões funcionais e estruturais. Amérindia 32: 11-25.

Castro Alves, Flávia de. 2010. Evolution of Case-Marking in Timbira. International Journal of American Linguistics 76: 439-475. 
Castro Alves, Flávia de. 2015. The Grammar of Auxiliaries in Canela: Description and Reconstruction. Paper presented at the Workshop in Diachronic Morphosyntax in South American Languages, Collegium de Lyon \& Laboratoire Dynamique Du Langage, Lyon, France, 28-30 May.

Castro Alves, Flávia de \& M. A. Reis Silva. 2007. Marcação de caso e aspecto progressivo em Canela e Mebengokre. Paper presented at the V Encontro de Línguas e Culturas Macro-Jê, Universidade de São Paulo, 3-5 May.

Comrie, Bernard. 1989. Language Universals and Linguistic Typology: Syntax and Morphology Oxford: Blackwell.

Croft, William. 2003. Typology and Universals. Cambridge: Cambridge University Press.

Dixon, R. M. W. 1979. Ergativity. Language 55: 59-138.

Dixon, R. M. W. 1994. Ergativity. Cambridge: Cambridge University Press.

Donohue, Mark \& Søren Wichmann, eds. 2008. The Typology of Semantic Alignment. Cambridge: Cambridge University Press.

Dourado, Luciana. 2001. Aspectos morfosintáticos da língua Panará (Jê). Ph.D. dissertation, Universidade Estadual de Campinas.

Dryer, Matthew S. 2007. Clause Types. Language Typology and Syntactic Description, vol 1, ed by T. Shopen, 224-275. Cambridge: Cambridge University Press.

Estival, Dominique \& John Myhill. 1988. Formal and Functional Aspects of the Development from Passive to Ergative Systems. Passive and Voice, ed. by M. Shibatani, 441-491. Amsterdam: John Benjamins.

Gildea, Spike. 1993a. The Rigid Postverbal Subject in Panare: A Historical Explanation. International Journal of American Linguistics 59: 44-63.

Gildea, Spike. 1993b. The Development of Tense Markers from Demonstrative Pronouns in Panare (Cariban). Studies in Language 17: 53-73.

Gildea, Spike. 1998. On Reconstructing Grammar: Comparative Cariban Morphosyntax. Oxford: Oxford University Press.

Gildea, Spike. 200o. On the Genesis of the Verb Phrase in Cariban Languages: Diversity Through Reanalysis. Reconstructing Grammar: Comparative Linguistics and Grammaticalization Theory, ed. by Spike Gildea, 65-106. Amsterdam: John Benjamins.

Gildea, Spike. 2003. The Venezuelan Branch of the Cariban Language Family. Amérindia 28: 7-32.

Gildea, Spike. 2004. Are There Universal Cognitive Motivations for Ergativity? L'ergativité en Amazonie, vol. 2, ed. by Francesc Queixalós, 1-37. Brasília: CNRS, IRD and the Laboratório de Línguas Indígenas, UnB.

Gildea, Spike. 2012. Linguistic Studies in the Cariban Family. Handbook of South American Languages, ed. by Lyle Campbell \& Veronica Grondona, 441-494. Berlin: Mouton de Gruyter. 
Gildea, Spike \& Flávia de Castro Alves. 2010. Nominative-Absolutive:Counter-Universal Split Ergativity in Jê and Cariban. Ergativity in Amazonia, ed. by Spike Gildea \& Francesc Queixalós, 159-199. Amsterdam: John Benjamins.

Gildea, Spike, Berend Hoff \& Sérgio Meira. 2010. The story of *ô in the Cariban family. Fieldwork and Linguistic Analysis in Indigenous Languages of the Americas, ed. by Andrea L. Berez, Daisy Rosenblum \& Jean Mulder. Language Documentation \& Conservation Special Publication No. 2, 91-123.

Gilij, Filippo S. 1780-1784. Saggio di Storia Americana, vols. 1-3. Rome. [1965. Ensayo de Historia Americana, vols. 1-3. Trans. Antonio Tovar. Caracas: Italgráfica].

Givón, Talmy. 1979. On Understanding Grammar. New York: Academic Press.

Givón, Talmy. 1980. The Drift away from Ergativity: Diachronic Potentials in Sherpa. Folia Linguistica 4: 41-6o.

Givón, Talmy. 2001. Syntax: An Introduction, vols. 1-2. Amsterdam: John Benjamins. Givón, Talmy. 2009. The Genesis of Syntactic Complexity. Amsterdam: John Benjamins. Goldberg, Adele E. 20o6. Constructions at Work: The Nature of Generalization in Language. Oxford: Oxford University Press.

Guillaume, Antoine. 2015. Reconstructing the Morphology of the Pronominal Systems of Takanan Languages. Paper Presented at the Workshop in Diachronic Morphosyntax in South American Languages, Collegium de Lyon \& Laboratoire Dynamique Du Langage, Lyon, France, 28-30 May.

Harris, Alice C. \& Lyle Campbell. 1995. Historical Syntax in Cross-Linguistic Perspective. Cambridge: Cambridge University Press.

Haspelmath, Martin. 2011. On S, A, P, T, and R as Comparative Concepts for Alignment Typology. Linguistic Typology 15: 535-567.

Hawkins, Robert E. 1998. Waiwai. Handbook of Amazonian Languages, vol. 4, ed. by Desmond C. Derbyshire \& Geoffrey K. Pullum, 3-202. Berlin: Mouton de Gruyter.

Heine, Bernd. 1994. Grammaticalization as an Explanatory Parameter. Perspectives on Grammaticalization, ed. by W. Pagliuca, 255-287. Amsterdam: John Benjamins.

Heine, Bernd \& Tania Kuteva. 2002. World Lexicon of Grammaticalization. Cambridge: Cambridge University Press.

Hewitt, Brian G. 1987. The Typology of Subordination in Georgian and Abkhaz. Berlin: Mouton de Gruyter.

Hoff, J. Berend. 1968. The Carib Language. The Hague: Martinus Nijhoff.

Koehn, Edward \& Sally Koehn. 1986. Apalai. Handbook of Amazonian Languages, ed. Desmond C. Derbyshire \& Geoffrey K. Pullum, vol. 1, 33-127. Berlin: Mouton de Gruyter.

Koptjevskaja-Tamm, Maria. 1993. Nominalizations. London \& New York: Routledge.

Malchukov, Andrej L. 2010. "Quirky" Case: Rare Phenomena in Case-Marking and their Implications for a Theory of Typological Distributions. Rethinking Universals: How 
Rarities Affect Linguistic Theory, ed. by J. Wohlgemuth \& M. Cysouw, 139-169. Berlin: Mouton.

Mattéi Muller, Marie-Claude. 1994. Diccionario Ilustrado Panare-Español, indice Español-Panare. Caracas: Comisión Quinto-Centenário.

Mattéi Muller, Marie-Claude. 2007. Voir et Savoir en Panaré (langue caribe du Venezuela). L'énonciation médiatisée II, ed by Z. Guentcheva \& J. Landaburu, 153170. Louvain-Paris: Peeters.

Meira, Sérgio. 1999. A Grammar of Tiriyó. Ph.D. dissertation, Rice University.

Meira, Sérgio. 200o. The Accidental Intransitive Split in the Cariban Family. Reconstructing Grammar: Comparative Linguistics and Grammaticalization, ed. by Spike Gildea, 201-23o. Amsterdam: John Benjamins.

Meira, Sérgio \& Bruna Franchetto. 2005. The Southern Cariban Languages and the Cariban Family. International Journal of American Linguistics 71:127-192.

Nonato, Rafael. 2014. Clause Chaining, Switch Reference and Coordination. Ph.D. dissertation, Massachusetts Institute of Technology.

Oliveira, Christiane C. 2003. Lexical Categories and Descriptives in Apinajé. International Journal of American Linguistics 69: 243-274.

Oliveira, Christiane C. 2005. The Language of the Apinajé People of Central Brazil. Ph.D. dissertation, University of Oregon.

Payne, Doris L. 1994. OVSu Versus VSuO in Panare (Cariban): Do Syntax and Discourse Match? Text 14: 581-610.

Payne, Thomas E. 1990. Ergativity and Transitivity in Panare (Carib). Amazonian Linguistics: Studies in Lowland South American Languages, ed. by Doris L. Payne 429-453. Austin: University of Texas Press.

Payne, Thomas E. 1997. Describing Morphosyntax: A Guide for Field Linguists. Cambridge: Cambridge University Press.

Payne, Thomas E. \& Doris Payne. 1999. Panare: A Cariban Language of Central Venezuela. 194pp. ms.

Payne, Thomas E. \& Doris Payne. 2013. A Typological Grammar of Panare: A Cariban Language of Central Venezuela. Leiden: Brill Press.

Popjes, Jack \& Jo Popjes. 1986. Canela-Krahô. Handbook of Amazonian Languages, Vol. 1, ed. by Desmond C. Derbyshire \& Geoffrey K. Pullum, 128-99. Berlin: Mouton de Gruyter.

Queixalós, Francesc \& Spike Gildea. 2010. Manifestations of Ergativity in Amazonia. Ergativity in Amazonia, ed. by S. Gildea \& F. Queixalós, 1-25. Amsterdam: John Benjamins.

Reis Silva, Maria A. 2001. Pronomes, ordem e ergatividade em Mẽbêngôkre (Kayapó). MA thesis, Universidade Estadual de Campinas.

Ribeiro, Eduardo \& Hein van der Voort. 2010. Nimuendajú Was Right: The Inclusion of the Jabutí Language Family in the Macro-Jê Stock. International Journal of American Linguistics 76: 517-570. 
Rodrigues, Aryon D. 2009. A Case of Affinity among Tupí, Karíb, and Macro-Jê. Revista Brasileira de Linguística Antropológica 1(1): 137-162.

Salanova, Andrés P. 2007. Nominalizations and Aspect. Ph.D. dissertation, Massachussets Institute of Technology.

Salanova, Andrés P. 2008. Uma análise unificada das construções ergativas em Mẽbêngôkre. Amérindia 32: 109-134.

Santos, Ludoviko C. 1997. Descrição de aspectos morfossintáticos da língua Suyá/ Kisêdjê (Jê). Ph.D. Dissertation, Universidade Federal de Santa Catarina.

Santos, Ludoviko C. 1999. Aspectos do Sistema de Marcação de Caso da Língua Suyá. Signum: Estudos da Linguagem 2: 231-242.

Stout, Mickey \& Ruth Thomson. 1974. Modalidade em kayapó. Série Linguística 3: 69-97. Tavares, Petronila S. 2005. A Grammar of Wayana. Ph.D. dissertation, Rice University. Traugott, Elizabeth C. \& Graeme Trousdale. 2013. Constructionalization and Constructional Change. Oxford: Oxford University Press.

Urban, Greg. 1985. Ergativity and Accusativity in Shokleng (Gê). International Journal of American Linguistics 51: 164-187.

Van de Velde, Freek, Hendrik de Smet, \& Lobke Ghesquière. 2013. On Multiple Source Constructions in Language Change. Studies in Language 37: 473-489.

Wiesemann, Ursula. 1972. Die Phonologische und Grammatische Struktur der Kaingáng-Sprache. Paris: Mouton.

Wiesemann, Ursula. 2002. Kaingáng-Português: Dicionário Bilíngue. Curitiba: Editora Evangélica Esperança.

Willis, David. 2011. Reconstructing Last Week's Weather: Syntactic Reconstruction and Brythonic Free Relatives. Journal of Linguistics 47(2): 407-446. 